Instytut Archeologii

Uniwersytetu Mikołaja Kopernika

w Toruniu

Daniel Makowiecki

\title{
DANE ARCHEOZOOLOGICZNE Z MIEJSCOWOŚCI BOCIEŃ (STA- NOWISKO 5) DO POZNANIA GOSPODARKI LUDNOŚCI KULTURY CERAMIKI WSTĘGOWEJ RYTEJ NA ZIEMI CHEŁMIŃSKIEJ
}

Zarys treści: W artykule zawarto dane archeozoologiczne uzyskane podczas badań pokonsumpcyjnych zbiorów faunistycznych, odkrytych w obiektach osady ludności kultury ceramiki wstęgowej rytej (fazy II i III). Ich szczegółowa analiza biologiczna oraz archeologiczna (kontekstowa) stała sie podstawą do rozważań na temat genezy zbadanego zbioru faunistycznego, znaczenia gatunków domowych i strategii gospodarczych w wytwarzaniu surowców pochodzenia zwierzęcego, niektórych cech środowiska przyrodniczego otoczenia osady oraz morfotypów zwierząt neolitycznych ziemi chełmińskiej.

\section{Wstęp}

Zasiedlenie ziemi chełmińskiej przez najstarsze społeczności rolnicze, które według taksonomii archeologicznej utożsamia się z twórcami kultury ceramiki wstęgowej rytej (KCWR), miało miejsce około 5400 BC (Kukawka 1997; Kukawka i in. 2002). Trzeba jednak zauważyć, że o ile wyznaczniki archeologiczne (źródła ruchome i obiekty zwarte) oraz ich periodyzacja były wystarczające do skonstruowania zachowań kulturowych, w tym niektórych gospodarczych, wspomnianych społeczności (np. Małecka-Kukawka 1994; 2001), to źródła będące bezpośrednimi wskaźnikami rolniczego sposobu zdobywania pożywienia, na przykład poprzez hodowlę ssaków domowych, należą do rzadkości w strefie ziemi chełmińskiej. Jak dotąd najpełniejszych informacji na ten temat dostarczyły wyniki badań osady odkrytej w Stolnie, na stanowisku 2 (Makowiecki 1987; 2003; Makowiecki, Godynicki 1993), której czas zasiedlenia określono na II fazę rozwojową KCWR. Kolejny zbiór szczątków zwierzęcych z obiektów tej samej kultury pochodzi z miejscowości: Annowo, stanowisko $7^{1}$ oraz Małe Radowiska, stanowisko 14 (Osipowicz i in. w druku) (tab. 1). Rozpoznane taksony faunistyczne niewatpliwie

\footnotetext{
${ }^{1}$ Niepublikowane dane autora z badań przeprowadzonych w $1992 \mathrm{r}$.
} 
pozwalają na wskazanie rolniczego sposobu zdobywania pożywienia, jednak obecność szczątków kręgowców wolno żyjących (ssaków i ryb) nie wyklucza tezy o praktykowaniu zajęć pozarolniczych. Trzeba też nadmienić, że pod względem liczebności zbadanych prób tylko ta ze Stolna wydaje się reprezentatywną na tyle, aby wnioskować o istotnym znaczeniu mięsa małych przeżuwaczy w menu grup KCWR. Liczba szczątków w pozostałych dwóch zbiorach jest niewielka i jakkolwiek różnią się od siebie wyraźnie odnotowanym poziomem częstości poszczególnych taksonów zoologicznych, to jednak obecność tych samych gatunków hodowlanych jest wystarczającą przesłanką do wnioskowania o wytwarzaniu pożywienia.

Tabela 1. Lista taksonów zoologicznych oraz liczba ich szczątków zarejestrowanych w osadach kultury ceramiki wstęgowej rytej na ziemi chełmińskiej

\begin{tabular}{|c|c|c|c|c|}
\hline Zwierzęta & $\begin{array}{l}\text { Bocień, sta- } \\
\text { nowisko } 5\end{array}$ & \begin{tabular}{|c|} 
Stolno, \\
stanowisko \\
2 \\
\end{tabular} & \begin{tabular}{|c|} 
Annowo, \\
stanowisko 7 \\
(obiekt 1)
\end{tabular} & $\begin{array}{c}\text { Małe Rado- } \\
\text { wiska, stano- } \\
\text { wisko } 14 \\
\end{array}$ \\
\hline Bydło (Bos primigenius f. taurus) & 366 & 108 & $3^{*}$ & 8 \\
\hline Świnia (Sus scrofa f. domestica) & 14 & 13 & 2 & 1 \\
\hline $\begin{array}{l}\text { Owca/koza (Ovis ammon f. aries/ } \\
\text { Capra aegagrus f. hircus) }\end{array}$ & 49 & 116 & 6 & 2 \\
\hline Koza (Capra aegagrus f. hircus) & 2 & 0 & 0 & 0 \\
\hline $\begin{array}{l}\text { Koń (Equus ferus silvestris/ Equus } \\
\text { ferus caballus?) }\end{array}$ & 1 & 0 & 0 & 0 \\
\hline Pies (Canis lupus f. familiaris) & 1 & 7 & 0 & 0 \\
\hline Jeleń (Cervus elaphus L., 1758) & 17 & 8 & 0 & 0 \\
\hline Łoś (Alces alces) & 1 & 0 & 0 & 0 \\
\hline $\begin{array}{l}\text { Sarna } \\
\text { (Capreolus capreolus L., 1758) }\end{array}$ & 1 & 1 & 0 & 0 \\
\hline Tur (Bos primigenius Boj. 1827) & 2 & 0 & 0 & 0 \\
\hline $\begin{array}{l}\text { Tur/Bydło (Bos primigenius Boj. } \\
\text { 1827/Bos primigenius f. taurus) }\end{array}$ & 8 & 0 & 0 & 1 \\
\hline Ptaki (Aves) & 0 & 2 & 0 & 0 \\
\hline $\begin{array}{l}\text { Żółw błotny } \\
\text { (Emys orbicularis L., 1758) }\end{array}$ & 2 & 0 & 0 & 0 \\
\hline Ryby (Pisces) & 0 & 379 & 0 & 0 \\
\hline Rozpoznane & 464 & 634 & 11 & 12 \\
\hline
\end{tabular}

* Ponadto około 100 bardzo drobnych fragmentów zębów, prawdopodobnie, pochodzących od jednego lub kilku osobników w wieku około 3-3,5 roku. 


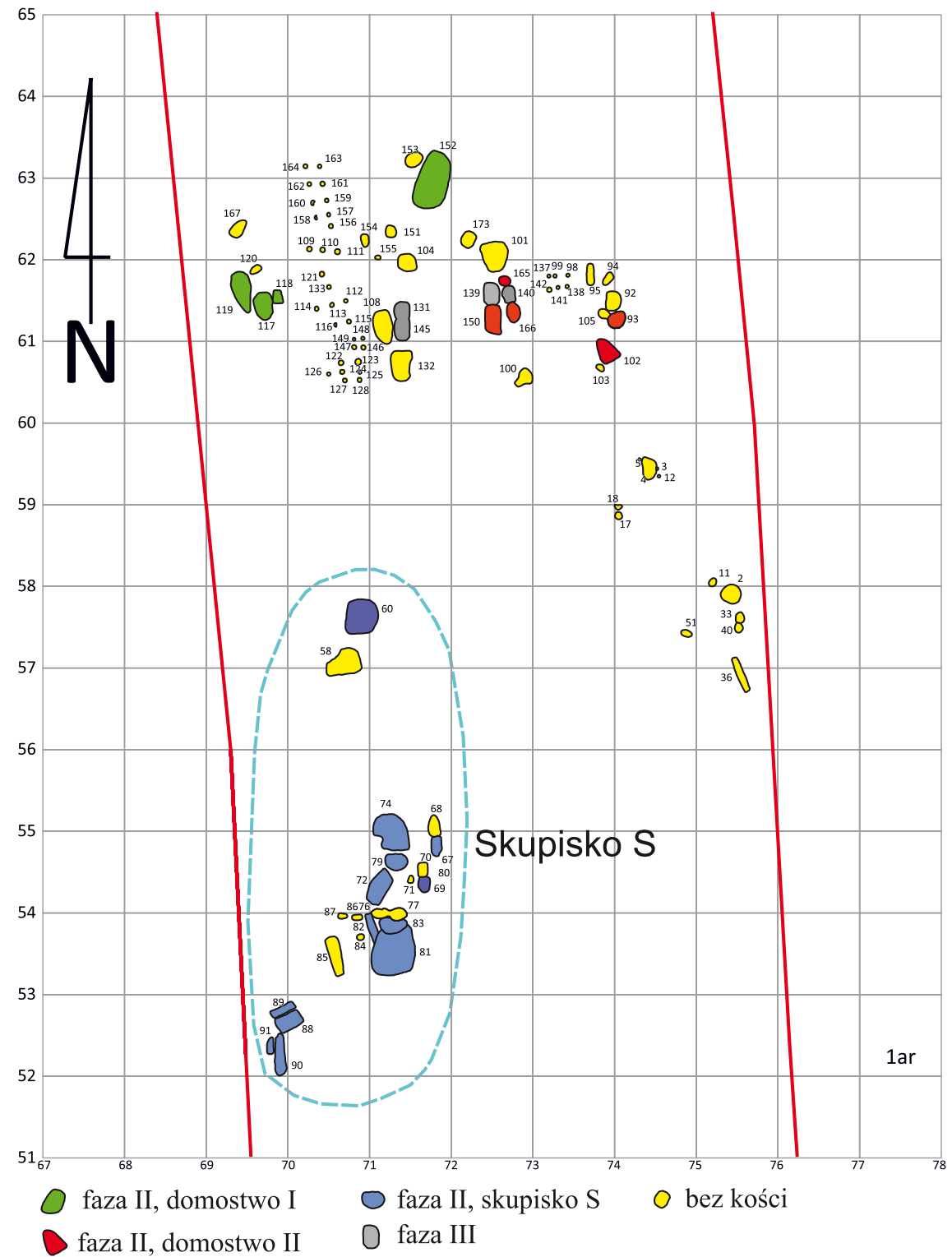

Ryc. 1. Bocień, gm. Chełmża, stanowisko 5. Planigrafia obiektów kultury ceramiki wstęgowej rytej oraz wydzielone strefy przestrzenno-funkcjonalne osady (rys. D. Makowiecki)

Fig. 1. Bocień, Chełmża commune, site 5. The feature planigraphy of LBPC and noticeable space-function areas (drawn by D. Makowiecki) 
Biorąc pod uwagę stan bazy źródłowej oraz uzyskane na jej podstawie informacje można zakładać, że każde kolejne odkrycie zbiorów kostnych, o wyraźnie większej liczebności niż w przypadku Annowa i Małych Radowisk powinno przyczynić się do lepszego poznania sposobów zdobywania surowców zwierzęcych przez ludność KCWR zamieszkującą ziemię chełmińską. Taka możliwość powstała wraz z odkryciem szczątków kostnych na stanowisku 5 w Bocieniu (gm. Chełmża), gdzie prowadzono ratownicze badania wykopaliskowe poprzedzające budowę autostrady A1 na terenie województwa kujawsko-pomorskiego. Niniejszy artykuł został poświęcony szczegółowej analizie nowych źródeł archeozoologicznych uzyskanych z tych badań. Datowano je na podstawie analizy cech stylistycznych i technologicznych naczyń ceramicznych. Ustalono, że jedynym homogennym, a zarazem licznym zbiorem są kości odkryte razem z tymi materiałami datowanymi na II i III fazę rozwoju kultury ceramiki wstęgowej rytej (Małecka-Kukawka w niniejszym tomie). Szczątki te znaleziono w obrębie domostw I i II oraz skupisku S (ryc. 1, aneks 1), ponadto zdecydowano się na włączenie do zbioru kości z warstwy, tj. z arów na których wystapiły jedynie obiekty KCWR ze skupiska S. Niewielką liczbę mocno zniszczonych szczątków wydobyto także z obiektów zawierających fragmenty naczyń ceramicznych $z$ dwóch i więcej jednostek chronologiczno-kulturowych (aneks 2), tylko wyjątkowo z jednej, na przykład młodszego okresu przedrzymskiego, wczesnego średniowiecza i czasów nowożytnych. Zważywszy na ubogość źródeł archeozoologicznych na ziemi chełmińskiej uznano, że uwzględnienie wyników analizy tych zbiorów może być przydatne do przyszłych studiów nad zasobami fauny, wykorzystywanymi przez ludność zamieszkującą wymieniony region w pradziejach.

\section{Podstawy metodyczne}

Szczegółowym rozważaniom analitycznym poddano jedynie szczątki kostne z obiektów ludności KCWR. Ze względu na niewielką liczebność tej kategorii źródeł pochodzących z innych taksonów chronologiczno-kulturowych, a tym samym niewielki zestaw informacji zoologicznych, pozostałe szczątki zestawiono jedynie w tabeli uwzględniając skład gatunkowy oraz zamieszczono na ich temat krótki komentarz.

Identyfikację szczątków przeprowadzono makroskopowo według procedur analitycznych stosowanych w badaniach archeozoologicznych, zawartych w opracowaniu D. Makowieckiego (2001). Ustalono ich przynależność gatunkową, anatomiczną oraz liczebność zbiorów kostnych, posługując się metodą 
fragmentów ${ }^{2}$. Wiek osobniczy (uboju) ssaków domowych oceniono głównie na podstawie stopnia rozwoju i zużycia uzębienia (Makowiecki 2001) oraz na podstawie kości długich, stosując w tym drugim przypadku kryteria O. Zietzschmanna i O. Kröllinga (1955).

Pomiary z kości zdjęto według zaleceń A. Driesch (1976), podając wartości w milimetrach. Wysokość w kłębie bydła i tura obliczono na podstawie współczynników V. I. Calkina (1960; 1970), a konia na podstawie wskaźnikowi M. Komosy i in. (1998). Wartości parametru podano w centymetrach. W przypadku gatunku Bos primigenius pomiary kości były podstawą do określenia formy domowej lub/i dzikiej, co uczyniono w oparciu o analizę porównawczą danych zliteratury (Gedymin 1965; Degerbøl, Fredskild 1970; Sobociński 1985; Kobryń, Lasota-Moskalewska 1989; Lasota-Moskalewska, Kobryń 1990; Döhle 1994).

Poza szczegółowym opisem zoologicznym, dwa procentowe wskaźniki zbiorów KCWR (udział szczątków rozpoznanych do nierozpoznanych oraz rozkład anatomiczny pozostałości bydła) stały się podstawą analizy przestrzennej. Inspiracją do jej przeprowadzenia były pozytywne efekty poznawcze takiego postępowania w przypadku analiz materiałów faunistycznych na innych stanowiskach neolitycznych (np. Marciniak 2005; 2006), z okresu wpływów rzymskich (Marciniak 2008), a także wczesnośredniowiecznych kompleksów osadniczych (np. Moździoch 1999; 2002; Makowiecki 2001; 2010).

\section{Zbiory faunistyczne KCWR i ich kwantyfikacja (ryc. 1-11; tab. 2-9)}

Łącznie zbadano 1115 kości, z których rozpoznano zaledwie 464 (41,6\% całej próby). Tak niski wskaźnik identyfikacji wynika z dużego rozdrobnienia materiałów, które było efektem dwóch zasadniczych procesów: a) kawałkowania, związanego z podziałem tuszy i porcjowaniem mięsa oraz b) niszczenia, zachodzącego w etapie podepozycyjnym. Poza tym, na stan zachowania miały wpływ liczne uszkodzenia powstałe podczas kolekcjonowania (tzw. ręcznego, tj. bez zastosowania sit i przemywania sedymentu) materiałów w trakcie eksploracji.

Szczątki kostne pochodziły przede wszystkim ze skupiska obiektów w południowej strefie (ryc. 2), wraz z materiałami z warstwy było to blisko $70 \%$ całego zbioru przyporządkowanego do KCWR. Pozostałe wydobyto z obrębu domostwa I, tylko znikomą część zaś z domostwa II. Również skupisko obiektów z III fazy rozwoju KCWR, odkryte między domostwami I a II, odznaczało się niskim wskaźnikiem odkrytych szczątków.

\footnotetext{
${ }^{2} \mathrm{~W}$ trakcie prac laboratoryjnych szczątki należące do jednego elementu kości liczono jako 1.
} 
Rozpatrując materiał archeozoologiczny pod względem grup zwierząt odnotowano zdecydowaną przewagę ssaków domowych. Tylko niewielki jego odsetek należy do ssaków dzikich oraz do gadów (tab. 1,2). W całym zbiorze blisko $80 \%$ szczątków pochodzi od bydła, które wśród gatunków domowych konsumpcyjnych stanowią aż 85\% (ryc. 3). Ssaki dzikie najliczniej są reprezentowane przez pozostałości jelenia, ponadto odnotowano łosia, sarnę i tura. Na skutek braku jednoznacznych kryteriów morfologicznych i metrycznych, zdecydowano się na przyporządkowanie części egzemplarzy z rodzaju Bos do umownego taksonu gatunkowego tur (Bos primigenius)/bydło (Bos primigenius f. taurus). Szczątki gadów pochodzą od żółwia błotnego (ryc. 4).

Pod względem składu anatomicznego najliczniejszym elementem pozostałości bydła są zęby oraz kości głowy (tab. 3), łącznie stanowiące 36,6\% zbioru (tab. 4). Pozostałe części stanowią nieznaczny udział, jednak należą niemal do wszystkich komponentów wzorcowego szkieletu. Ze względu na ich położenie w tuszy, najwięcej elementów pochodzi z klatki piersiowej (żebra), następnie z łopatki oraz udźca. Udział dwóch ostatnich jest zbliżony do siebie (tab. 4), podobnie jak liczba kości śródręcza i śródstopia (tab. 3).

Odrębną próbę stanowią kości, które nie zostały sklasyfikowane pod względem anatomicznym, jednak ich wygląd ogólny w zestawieniu z rozpoznanymi szczątkami, z jednej strony bydła, z drugiej mniejszych gatunków (owcy/kozy, świni), był przesłanką do uznania, że pochodzą od pierwszego

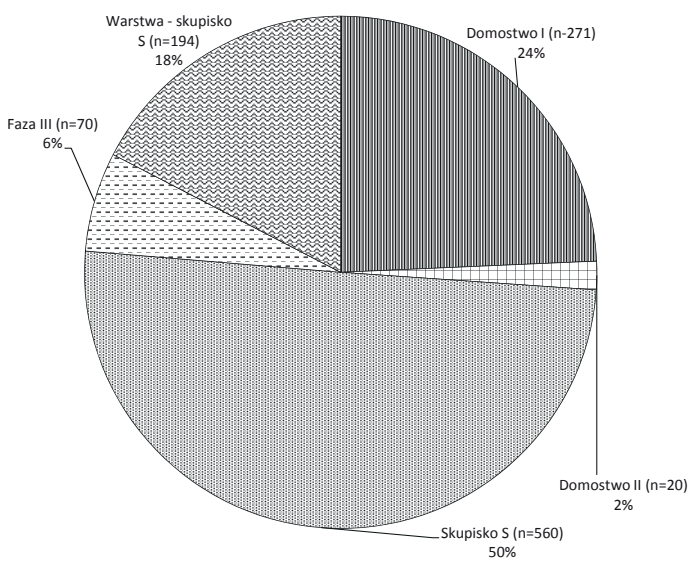

Ryc. 2. Bocień, gm. Chełmża, stanowisko 5. Udział szczątków zwierzęcych w strefach przestrzenno-funkcjonalnych osady ludności kultury ceramiki wstęgowej rytej (n=1115) (rys. D. Makowiecki)

Fig. 2. Bocień, commune Chełmża, site 5. The pie chart of animal remains (\%) in the space-function areas of the LBPC settlement (NISP=1115) (drawn by D. Makowiecki) 


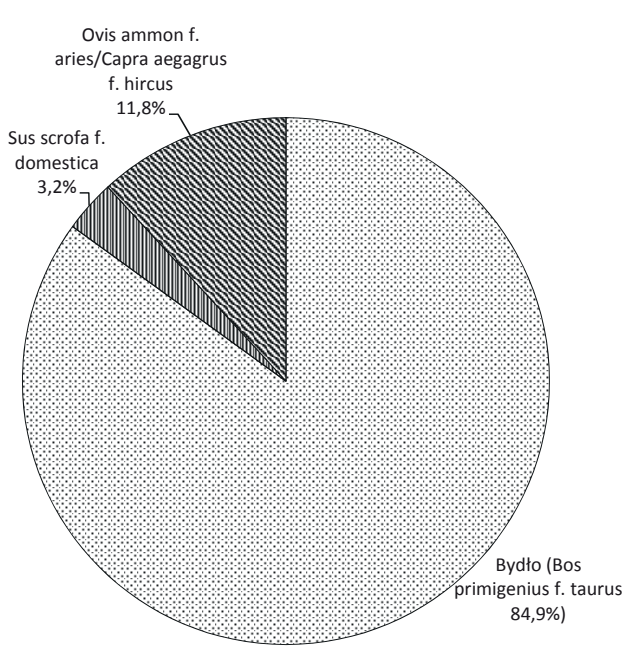

Ryc. 3. Bocień, gm. Chełmża, stanowisko 5. Udział szczątków gatunków domowych konsumpcyjnych (n=431) (rys. D. Makowiecki)

Fig. 3. Bocień, Chełmża commune, site 5 . The pie chart of domestic species $(\mathrm{NISP}=431)$ (drawn by D. Makowiecki)

Tabela 2. Bocień, gm. Chełmża, stanowisko 5. Kultura ceramiki wstęgowej rytej. Szczątki kostne według grup zoologicznych

\begin{tabular}{|l|c|c|}
\hline \multicolumn{1}{|c|}{ Grupa zwierząt } & n & \% \\
\hline Ssaki domowe & 432 & 93,12 \\
\hline Ssaki dzikie & 22 & 4,7 \\
\hline Tur/bydło & 8 & 1,7 \\
\hline Gady & 2 & 0,4 \\
\hline Razem & $\mathbf{4 6 4}$ & $\mathbf{1 0 0}$ \\
\hline
\end{tabular}

z wymienionych ssaków. Kości te to najczęściej odpryski od egzemplarzy rozpoznanych, część z nich niewątpliwie należy do odrębnych elementów szkieletu, zwiększających liczbowy i procentowy udział bydła. Ssaki dzikie, takie jak jeleń, łoś i sarna są reprezentowane jedynie przez fragmenty poroża (ryc. 5, 6).

Skład anatomiczny szczątków bydła, jako najbardziej reprezentatywny ze względu na liczebność i elementy szkieletu, prezentuje się odmiennie dla dwóch stref - skupiska południowego oraz domostwa I (ryc. 7). W obrębie pierwszej, w porównaniu do drugiej, odnotowano mniej elementów głowy, za to więcej żeber, kręgów szyjnych oraz kości kończyn, ręki i stopy.

Wiek zębowy śmierci bydła oceniono na podstawie 11 obserwacji (tab. 5). Najliczniejszą grupę w stadzie stanowiły osobniki około 3,5 roku, pojedyncze sztuki przyporządkowano do klasy 4-6 i 25-28 miesięcy oraz 3,5-5 lat. Obserwacje wieku osobniczego uzupełniono analizą stopnia rozwoju kości długich; w ten sposób uzyskano dane dla 102 egzemplarzy ${ }^{3}$ (tab. 6). Jakkolwiek

\footnotetext{
${ }^{3}$ Niestety, nie można bez zastrzeżeń utożsamiać tej liczby z liczbą osobników. Niekiedy jednak badacze przyjmują, że jedna kość pochodzi od jednego osobnika.
} 
Tabela 3. Bocień, gm. Chełmża, stanowisko 5. Kultura ceramiki wstęgowej rytej. Szczątki kostne według elementów szkieletu

\begin{tabular}{|c|c|c|c|c|c|c|c|c|c|c|c|}
\hline Elementy & 串 & 离 & 宽 & 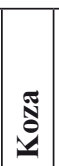 & 音 & $\stackrel{\tilde{E}}{n}$ & : & $\ddot{\omega}$ & 焉 & $\Xi$ & 总 \\
\hline Możdżeń & 0 & 0 & 0 & 1 & 0 & 0 & 0 & 0 & 0 & 0 & 0 \\
\hline Poroże & 0 & 0 & 0 & 1 & 0 & 0 & 17 & 1 & 1 & 0 & 0 \\
\hline Czaszka & 26 & 1 & 0 & 0 & 0 & 0 & 0 & 0 & 0 & 0 & 0 \\
\hline Żuchwa & 46 & 1 & 1 & 0 & 0 & 0 & 0 & 0 & 0 & 0 & 1 \\
\hline Zęby & 23 & 0 & 0 & 0 & 0 & 0 & 0 & 0 & 0 & 0 & 0 \\
\hline Ząb górny & 20 & 0 & 1 & 0 & 0 & 0 & 0 & 0 & 0 & 0 & 0 \\
\hline Ząb dolny & 10 & 1 & 1 & 0 & 0 & 0 & 0 & 0 & 0 & 0 & 0 \\
\hline Ząb górny $\mathrm{M}^{2}$ & 1 & 0 & 0 & 0 & 0 & 0 & 0 & 0 & 0 & 0 & 0 \\
\hline Ząb górny $\mathrm{M}^{3}$ & 4 & 0 & 0 & 0 & 0 & 0 & 0 & 0 & 0 & 0 & 0 \\
\hline Ząb dolny $\mathrm{M}_{3}$ & 4 & 0 & 0 & 0 & 0 & 0 & 0 & 0 & 0 & 0 & 0 \\
\hline Kręgi szyjne & 9 & 0 & 0 & 0 & 0 & 0 & 0 & 0 & 0 & 0 & 0 \\
\hline Kręg szyjny I & 1 & 0 & 2 & 0 & 0 & 0 & 0 & 0 & 0 & 0 & 0 \\
\hline Kręgi piersiowe & 4 & 0 & 0 & 0 & 0 & 0 & 0 & 0 & 0 & 0 & 0 \\
\hline Kręgi lędźwiowe & 7 & 0 & 0 & 0 & 0 & 0 & 0 & 0 & 0 & 0 & 0 \\
\hline Kość krzyżowa & 1 & 0 & 0 & 0 & 0 & 0 & 0 & 0 & 0 & 0 & 0 \\
\hline Żebra & 51 & 3 & 1 & 0 & 0 & 0 & 0 & 0 & 0 & 0 & 0 \\
\hline Łopatka & 12 & 0 & 1 & 0 & 0 & 0 & 0 & 0 & 0 & 0 & 2 \\
\hline Kość ramienna & 15 & 1 & 7 & 0 & 0 & 0 & 0 & 0 & 0 & 1 & 0 \\
\hline Kość promieniowa & 7 & 1 & 6 & 0 & 0 & 1 & 0 & 0 & 0 & 0 & 2 \\
\hline Kość łokciowa & 4 & 1 & 2 & 0 & 0 & 0 & 0 & 0 & 0 & 0 & 0 \\
\hline Kości promieniowa i łokciowa & 3 & 0 & 0 & 0 & 0 & 0 & 0 & 0 & 0 & 0 & 0 \\
\hline Kości nadgarstka & 9 & 0 & 0 & 0 & 0 & 0 & 0 & 0 & 0 & 0 & 0 \\
\hline Kości śródręcza & 20 & 2 & 2 & 0 & 0 & 0 & 0 & 0 & 0 & 0 & 0 \\
\hline Miednica & 5 & 0 & 2 & 0 & 0 & 0 & 0 & 0 & 0 & 0 & 0 \\
\hline Kość udowa & 15 & 0 & 1 & 0 & 0 & 0 & 0 & 0 & 0 & 0 & 0 \\
\hline Kość piszczelowa & 11 & 0 & 10 & 0 & 0 & 0 & 0 & 0 & 0 & 0 & 0 \\
\hline Kostka boczna & 1 & 0 & 0 & 0 & 0 & 0 & 0 & 0 & 0 & 0 & 0 \\
\hline Kości stępu & 2 & 1 & 0 & 0 & 0 & 0 & 0 & 0 & 0 & 0 & 0 \\
\hline Kość piętowa & 2 & 0 & 0 & 0 & 0 & 0 & 0 & 0 & 0 & 0 & 0 \\
\hline Kość skokowa & 1 & 0 & 2 & 0 & 0 & 0 & 0 & 0 & 0 & 1 & 1 \\
\hline Kość ośrodkowo-czwarta & 1 & 0 & 0 & 0 & 0 & 0 & 0 & 0 & 0 & 0 & 0 \\
\hline Kości śródstopia & 22 & 0 & 5 & 0 & 0 & 0 & 0 & 0 & 0 & 0 & 0 \\
\hline Kości śródręcza/śródstopia & 10 & 1 & 3 & 0 & 0 & 0 & 0 & 0 & 0 & 0 & 0 \\
\hline Człon palcowy 1 & 7 & 1 & 2 & 0 & 0 & 0 & 0 & 0 & 0 & 0 & 0 \\
\hline Człon palcowy 1 przedni & 0 & 0 & 0 & 0 & 1 & 0 & 0 & 0 & 0 & 0 & 0 \\
\hline Człon palcowy 2 & 7 & 0 & 0 & 0 & 0 & 0 & 0 & 0 & 0 & 0 & 2 \\
\hline Człon palcowy 3 & 3 & 0 & 0 & 0 & 0 & 0 & 0 & 0 & 0 & 0 & 0 \\
\hline Trzeszczki & 2 & 0 & 0 & 0 & 0 & 0 & 0 & 0 & 0 & 0 & 0 \\
\hline Razem & 366 & 14 & 49 & 2 & 1 & 1 & 17 & 1 & 1 & 2 & 8 \\
\hline Nieoznaczone & $\pm 290 *$ & & & & & & & & & & \\
\hline
\end{tabular}

* Drobne fragmenty kości bydła (tura/bydła?) pozbawione cech morfologicznych, bez możliwości jednoznacznej identyfikacji gatunkowej i anatomicznej (obiekty: 67, 74, 79, 119, 145). 
Tabela 4. Bocień, gm. Chełmża, stanowisko 5. Kultura ceramiki wstęgowej rytej. Szczątki kostne bydła, świni oraz owcy/kozy według zespołów kości

\begin{tabular}{|l|l|c|c|c|c|}
\hline \multirow{2}{*}{ Tusza* } & \multirow{2}{*}{ Zespól } & \multicolumn{2}{c|}{ Bydło } & Świnia & Owca/koza \\
\cline { 3 - 7 } & & $\mathbf{n}$ & $\mathbf{\%}$ & $\mathbf{n}$ & $\mathbf{n}$ \\
\hline Głowizna & Kości głowy & 134 & 36,6 & 3 & 5 \\
\hline Stopki & Kości ręki i stopy & 86 & 23,5 & 5 & 14 \\
\hline Karkówka & Kręgi szyjne & 10 & 2,7 & 0 & 2 \\
\hline Rozbratel, antrykot, & Kręgi piersiowe & 4 & 1,1 & 0 & 0 \\
\hline Rostbef, schab & Kręgi lędźwiowe & 7 & 1,9 & 0 & 0 \\
\hline Biodrówka & Kość krzyżowa & 1 & 0,3 & 0 & 0 \\
\hline Żeberka & Żebra, mostek & 51 & 13,9 & 3 & 1 \\
\hline $\begin{array}{l}\text { Szynka przednia, goleńn, } \\
\text { golonka }\end{array}$ & $\begin{array}{l}\text { Kości ramienia } \\
\text { i przedramienia }\end{array}$ & 41 & 11,2 & 3 & 16 \\
\hline $\begin{array}{l}\text { Szynka, goleń tylna, } \\
\text { golonka }\end{array}$ & $\begin{array}{l}\text { Kości miednicy, uda } \\
\text { i podudzia }\end{array}$ & 32 & 8,7 & 0 & 13 \\
\hline Razem & \multicolumn{2}{|c|}{$\mathbf{3 6 6}$} & $\mathbf{1 0 0}$ & $\mathbf{1 4}$ & $\mathbf{5 1}$ \\
\hline
\end{tabular}

* Według współczesnych kryteriów technologicznych (Makowiecki 2001; tam dalsza literatura).

najliczniejsze znich pochodząod zwierząt dorosłych (adultus), tojednak te przynależne do klas młodszych (juvenis i subadultus) stanowią dosyć wysoki odsetek, dlatego też łącznie wyraźnie przeważają. W przypadku pozostałych zwierząt odnośnie do wieku śmierci uzyskano nieliczne dane; dla jednej świni było to około 12-16 miesięcy (M2+), a dla owcy/kozy między 4 a 8 miesiącem (M1+).

Na niektórych kościach bydła odnotowano płytkie, wąskie wgłębienia, o ukośnym przebiegu w stosunku do osi kości długiej (ryc. 8, 9). Posługując się danymi zebranymi przez L. Binforda (1981) uznano, że są to negatywy ostrzy (noży) kamiennych (krzemiennych), używanych do oddzielania mięsa od kości, tzw. ślady filetowania. Z kulinarną obróbką mięsa czy szpiku można też łączyć czarne zabarwienia na kościach bydła i owcy, które powstały w wyniku ich kontaktu z ogniem (tab. 7).

Innymi rodzajami śladów działalności człowieka są nacięcia na części poroży jelenia (ryc. 5) i łosia (ryc. 6). Niektóre z nich powstały podczas użytkowania narzędzi wytworzonych z tego surowca. Kilka egzemplarzy poroży to tzw. zrzutki (ryc. 5: d; tab. 7). Obok poroża do wyrobu narzędzi wykorzystywano kości zwierząt domowych. Jeden z przedmiotów, prawdopodobnie dłuto, wykonano z kości śródstopia bydła (ryc. 10). Ponadto znaleziono dwie uszkodzone płytki kościane, których przynależność gatunkowa i anatomiczna były trudne do określenia (ryc. 11).

W ostatnim etapie analiz źródłowych przeprowadzono pomiary egzemplarzy; w porównaniu do globalnej liczby rozpoznanych kości było ich niewiele, 


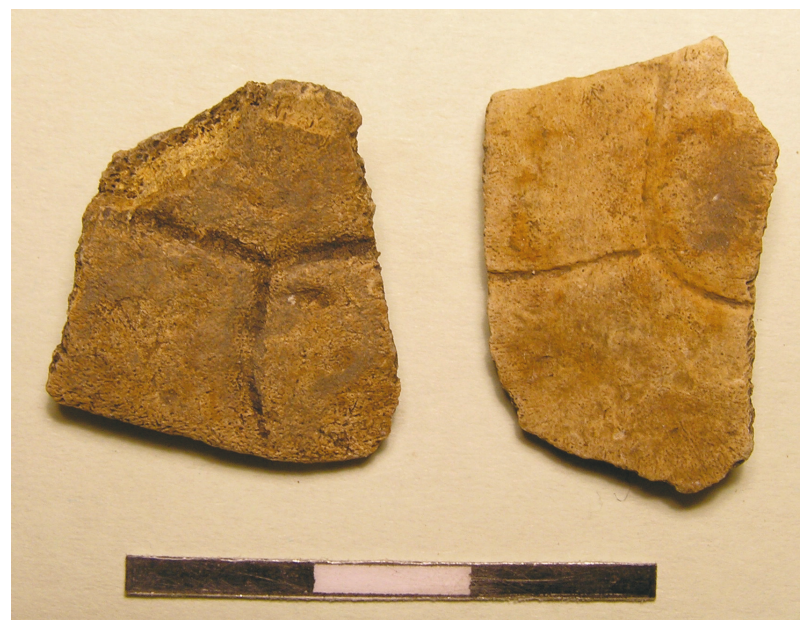

Ryc. 4. Bocień, gm. Chełmża, stanowisko 5. Żółw błotny (Emys orbicularis) - fragmenty karapaksu - obiekt 74 (fot. D. Makowiecki)

Fig. 4. Bocień, Chełmża commune, site 5. The European pond turtle (Emys orbicularis) fragment of carapace - feature 74 (phot. by D. Makowiecki)

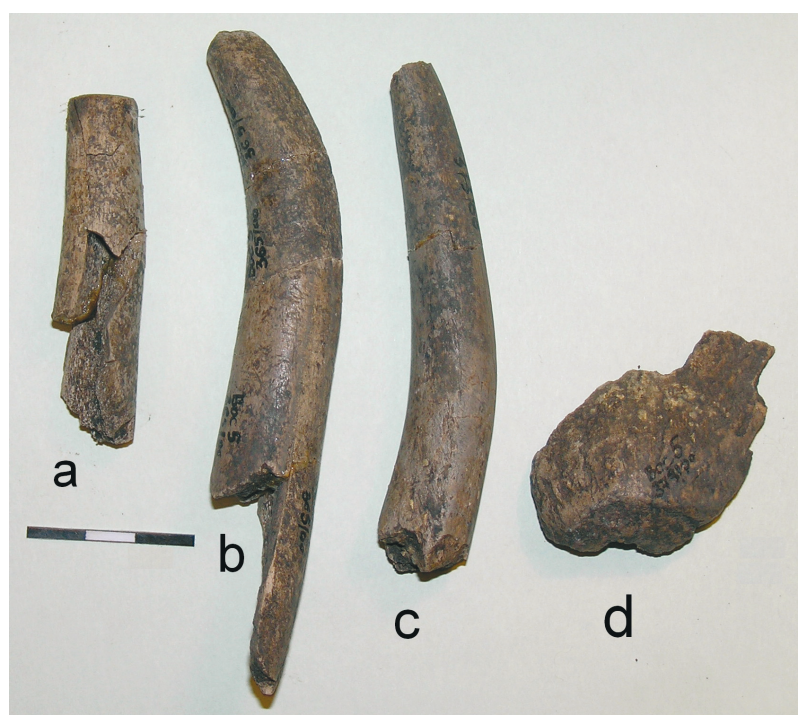

Ryc. 5. Bocień, gm. Chełmża, stanowisko 5. Jeleń (Cervus elaphus), poroże - a, b: odnoga tyki lub korony ze śladami obróbki (obiekt 118), c: odnoga tyki lub korony ze śladami obróbki (obiekt 119), d: zrzutek ze śladami obróbki - fragment motyki? (obiekt 119) (fot. D. Makowiecki)

Fig. 5. Bocień, Chełmża commune, site 5. Red deer (Cervus elaphus), antler - a, b: a tine of beams or crown with work traces - feature 118, c: tine of beams or crown with work traces - feature 119 , d: shed beam with work traces fragment of antler hoe (?) - feature 119 (phot. by D. Makowiecki) 


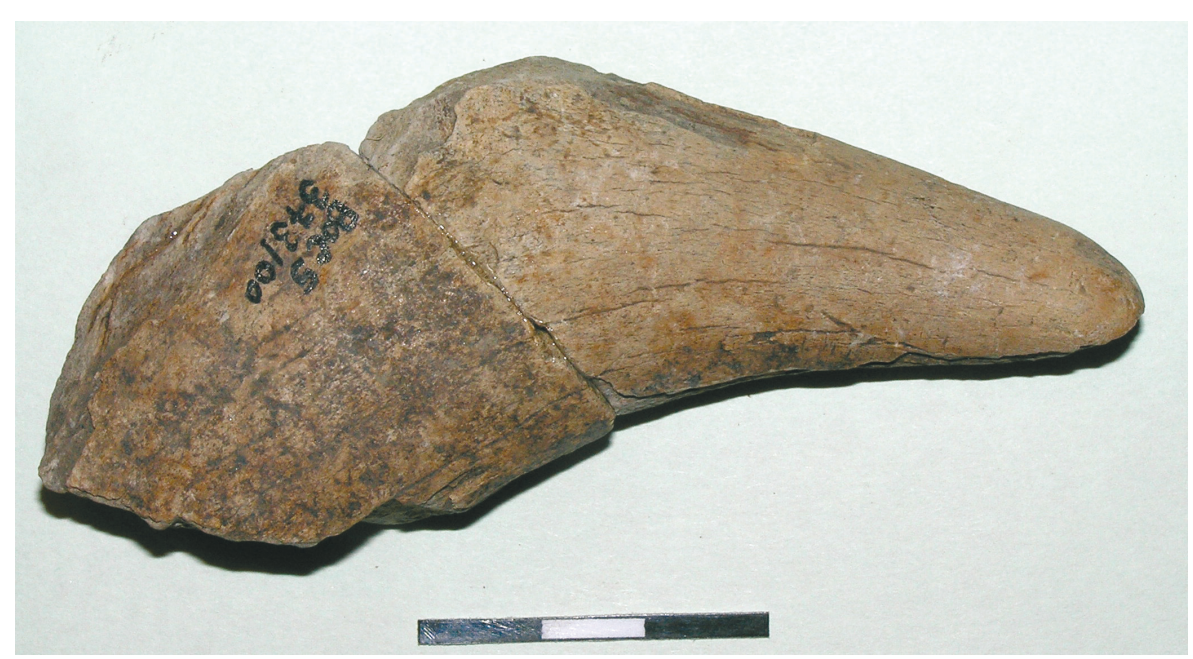

Ryc. 6. Bocień, gm. Chełmża, stanowisko 5. Łoś (Alces alces) - poroże ze śladami obróbki - obiekt 119 (fot. D. Makowiecki)

Fig. 6. Bocień, Chełmża commune, site 5. Elk (Alces alces) - an antler fragment with work traces - feature 119 (phot. by D. Makowiecki)

pochodziły od bydła, tura oraz konia, prawdopodobnie dzikiego (tab. 8, 9). $\mathrm{Z}$ tych tylko pojedyncze (jako całe) stały się podstawą do oszacowania wysokości w kłębie. Jeden osobnik bydła mierzył około $132 \mathrm{~cm}$, tura 151,5 cm i konia $129 \mathrm{~cm}$. Ponadto jedna z kości skokowych mogła należeć do tura (samicy) lub bydła (samca) o wysokości około $144 \mathrm{~cm}$.

\section{Pozostałe materiaty}

Szczątki kostne ze zbiorów przemieszanych odznaczały się bardzo złym stanem zachowania, najczęściej były to bardzo drobne fragmenty, których identyfikacja gatunkowa i anatomiczna była niemożliwa. Wśród nielicznie rozpoznanych najczęściej występowały kości bydła, następnie małych przeżuwaczy, świni, konia oraz dzika (tab. 10). Na podstawie otrzymanych danych można jedynie stwierdzić, że kolejne, po ludności KCWR, grupy zdobywały pożywienie mięsne i surowce pochodzenia zwierzęcego głównie dzięki hodowli ssaków domowych.

\section{Ocena kulturowa danych źródtowych ze zbioru KCWR}

Odkryty zbiór faunistyczny charakteryzuje się nie tylko znaczną liczebnością, lecz także zakresem informacji, większym niż w przypadku mate- 


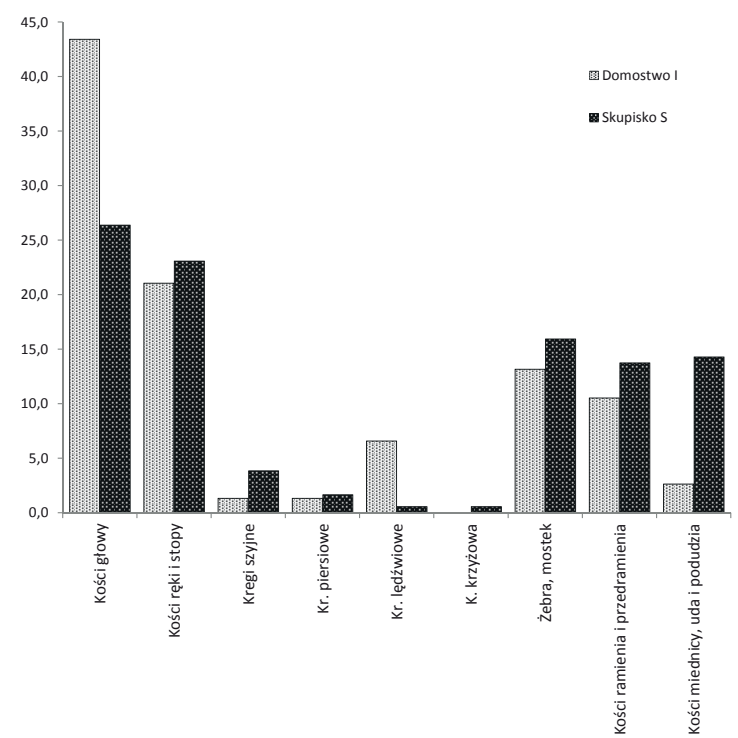

Ryc. 7. Bocień, gm. Chełmża, stanowisko 5. Udział zespołów kości bydła w dwóch strefach przestrzenno-funkcjonalnych osady ludności kultury ceramiki wstęgowej rytej (rys. D. Makowiecki)

Fig. 7. Bocień, Chełmża commune, site 5. Bar chart of cattle bone (\%) according to anatomical composition given in two space areas of the LBPC settlement (drawn by D. Makowiecki)

riałów dotychczas znanych z ziemi chełmińskiej. Dlatego można uznać, że powinny być one przydatne do interpretacji historyczno-kulturowych możliwych na gruncie archeozoologii, a odnoszących się do następujących kwestii: a) genezy omawianego zbioru faunistycznego, b) znaczenia gatunków domowych w wytwarzaniu surowców pochodzenia zwierzęcego, c) stosowanych strategii w wytwarzaniu surowców pochodzenia zwierzęcego, d) niektórych cech środowiska przyrodniczego otoczenia osady oraz e) morfotypów neolitycznych zwierząt ziemi chełmińskiej. Interpretacje te, ze względu na regionalny zakres uzyskanych informacji źródłowych, będą dotyczyć głównie osady ludności KCWR w Bocieniu oraz nieco szerzej, ziemi chełmińskiej.

Odnosząc się do genezy depozytu należy zwrócić uwagę na kilka charakterystycznych cech, wskazujących jego antropogeniczne (kulturowe), przede wszystkim pokonsumpcyjne pochodzenie. Należą do nich: a) znaczny stopień zniszczenia materiałów, wyrażony dość niskim odsetkiem rozpoznanych szczątków w stosunku do nierozpoznanych, b) obecność egzemplarzy z negatywami powstałymi w trakcie przygotowywania części umięśnionych do spożycia, c) obecność kości o czarnym zabarwieniu, będącym wynikiem oddziaływania ognia. O kulturowej genezie zbioru można wnioskować także 
Tabela 5. Bocień, gm. Chełmża, stanowisko 5. Kultura ceramiki wstęgowej rytej. Wiek uboju bydła na podstawie uzębienia

\begin{tabular}{|l|c|c|}
\hline \multicolumn{1}{|c|}{ Stan uzębienia } & Wiek uboju & $\mathrm{N}$ \\
\hline Zęby mleczne wyrośnięte & do 3 miesięcy & 0 \\
\hline M1 w stadium wyrastania & $4-6$ miesięcy & 1 \\
\hline M1 wyrośnięty & $7-14$ miesięcy & 0 \\
\hline M2 w stadium wyrastania & $15-18$ miesięcy & 1 \\
\hline M2 wyrośnięty & $19-24$ miesiące & 0 \\
\hline M3 w stadium wyrastania & 25-28 miesięcy & 1 \\
\hline Pd2/Pd4 w stadium wymiany na P2/P4 & 29-34 miesiące & 0 \\
\hline M3 lekko starty (M3+/+) & około 3,5 roku & 4 \\
\hline M3 lekko starty (M3+/++) & & 2 \\
\hline M3 lekko starty (M3+/+++) & & 1 \\
\hline M3 lekko-średnio starty (M3++) & 3,5-5 lat & 1 \\
\hline M3 średnio starty (M3+++) & 5-7 lat & 0 \\
\hline M3 średnio-mocno starty (M3++++) & 7-10 lat & 0 \\
\hline M3 mocno starty (M3+++++) & powyżej 10 lat & 0 \\
\hline Razem & & $\mathbf{1 1}$ \\
\hline
\end{tabular}

Tabela 6. Bocień, gm. Chełmża, stanowisko 5. Kultura ceramiki wstęgowej rytej. Wiek uboju bydła

\begin{tabular}{|c|c|c|c|c|}
\hline Element anatomiczny & Juvenis & $\begin{array}{c}\text { Subadultus/ } \\
\text { adultus }\end{array}$ & Subadultus & Adultus \\
\hline$\overline{\text { Czaszka }}$ & 1 & 0 & 0 & 1 \\
\hline Żuchwa & 1 & 0 & 1 & 0 \\
\hline Zęby & 0 & 13 & 0 & 1 \\
\hline Ząb górny & 0 & 0 & 7 & 12 \\
\hline Ząb dolny & 2 & 0 & 3 & 5 \\
\hline Zab górny $\mathrm{M}^{2}$ & 0 & 0 & 1 & 0 \\
\hline Ząb górny $\mathrm{M}^{3}$ & 0 & 0 & 1 & 3 \\
\hline Ząb dolny $\mathrm{M}_{3}$ & 0 & 0 & 0 & 4 \\
\hline Kręgi lędźwiowe & 1 & 0 & 0 & 1 \\
\hline Łopatka & 1 & 0 & 0 & 0 \\
\hline Kość ramienna & 3 & 0 & 0 & 1 \\
\hline Kości śródręcza & 1 & 0 & 7 & 1 \\
\hline Kość udowa & 0 & 0 & 2 & 0 \\
\hline Kość piszczelowa & 2 & 0 & 2 & 3 \\
\hline Kości śródstopia & 7 & 0 & 5 & 0 \\
\hline Kości śródręcza/śródstopia & 2 & 0 & 1 & 3 \\
\hline Człon palcowy 1 & 1 & 0 & 0 & 0 \\
\hline Człon palcowy 2 & 0 & 0 & 0 & 1 \\
\hline Człon palcowy 3 & 1 & 0 & 0 & 0 \\
\hline $\operatorname{Razem}(\mathrm{N}=102)$ & 23 & 13 & 30 & 36 \\
\hline$\%$ & 22,5 & 12,7 & 29,4 & 35,3 \\
\hline
\end{tabular}




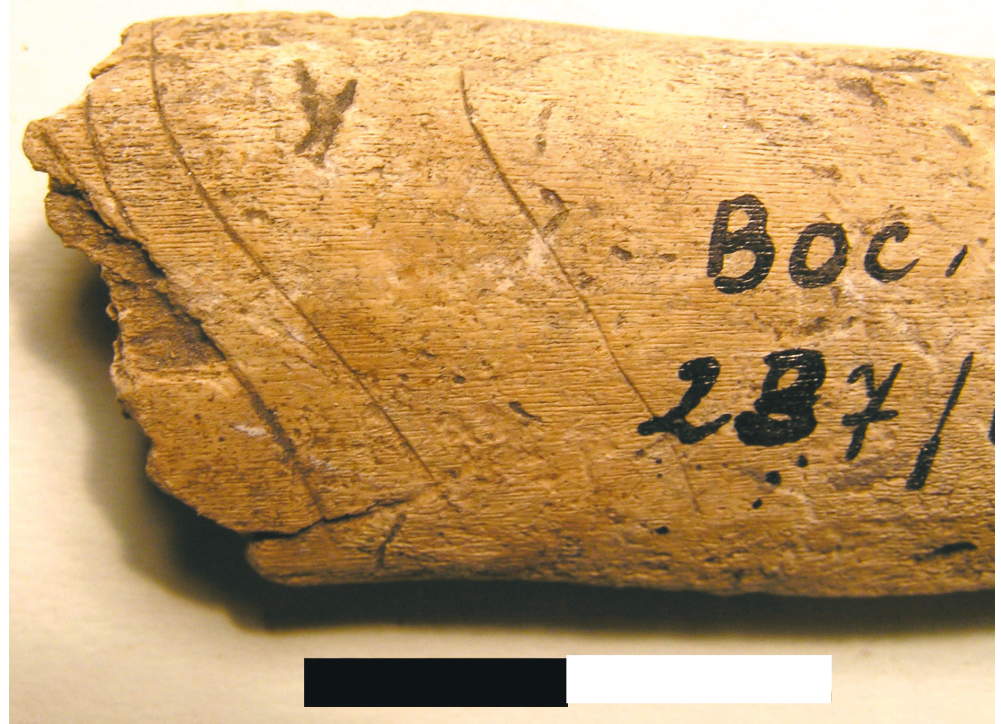

Ryc. 8. Bocień, gm. Chełmża, stanowisko 5. Bydło (Bos primigenius f. taurus) - kręg lędźwiowy ze śladami filetowania; trzon - widok od strony dobrzusznej - obiekt 74 (fot. D. Makowiecki)

Fig. 8. Bocień, Chełmża commune, site 5. Cattle (Bos primigenius f. taurus) - lumbal vertebra with traces of filleting; corpus - the ventra view - feature 74 (phot. by D. Makowiecki)

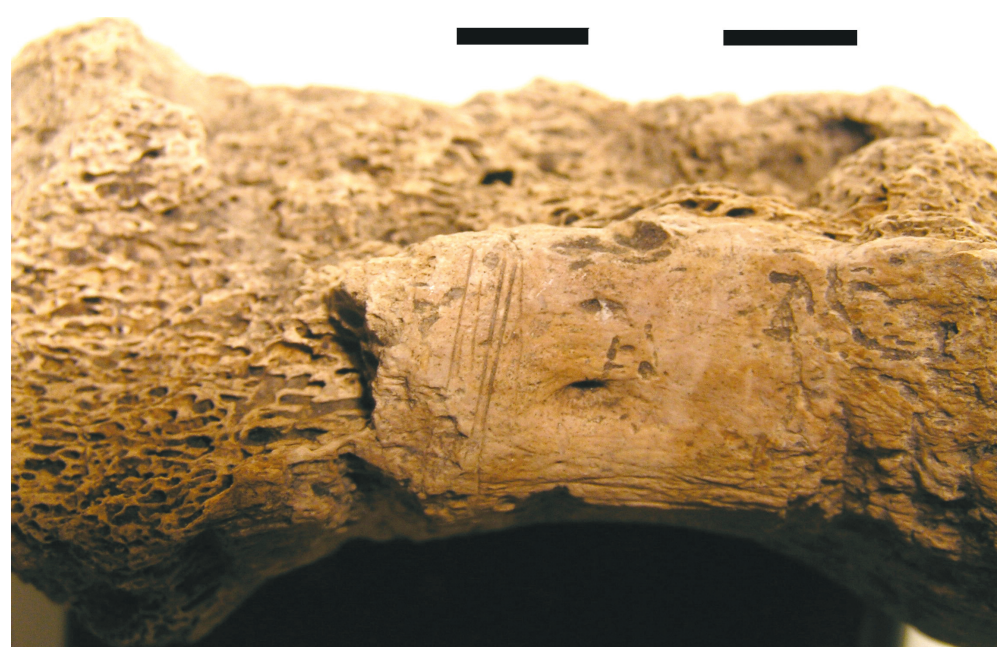

Ryc. 9. Bocień, gm. Chełmża, stanowisko 5. Bydło (Bos primigenius f. taurus) - żebro ze śladami filetowania - obiekt 74 (rys. D. Makowiecki)

Fig. 9. Bocień, Chełmża commune, site 5. Cattle (Bos primigenius f. taurus) - a rib with traces of filleting - feature 74 (phot. by D. Makowiecki) 
Tabela 7. Bocień, gm. Chełmża, stanowisko 5. Kultura ceramiki wstęgowej rytej. Kości ze śladami pochodzenia antropogenicznego (przedmioty, ślady ognia i filetowania)

\begin{tabular}{|c|c|c|c|c|c|}
\hline 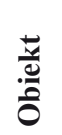 & 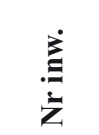 & 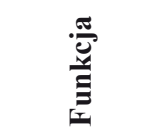 & 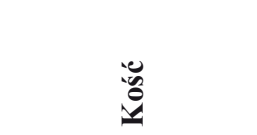 & 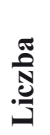 & 荡 \\
\hline \multicolumn{6}{|c|}{ Bydło } \\
\hline 119 & $373 / 00$ & jama & Żuchwa & 2 & nadpalone \\
\hline 118 & $365 / 00$ & jama & Żuchwa & 1 & ślady filetowania \\
\hline 74 & $237 / 00$ & $\begin{array}{l}\text { jama śmiet- } \\
\text { niskowa }\end{array}$ & Kręg szyjny I & 1 & ślady filetowania \\
\hline 74 & $237 / 00$ & $\begin{array}{l}\text { jama śmiet- } \\
\text { niskowa }\end{array}$ & Kręgi lędźwiowe & 1 & $\begin{array}{l}\text { ślady filetowania } \\
\text { na trzonie }\end{array}$ \\
\hline 74 & $237 / 00$ & $\begin{array}{l}\text { jama śmiet- } \\
\text { niskowa }\end{array}$ & Żebra & 1 & ślady filetowania \\
\hline 79 & $179 / 00$ & jama & Kręgi szyjne & 1 & ślady ognia \\
\hline 118 & $365 / 00$ & jama & Kręgi szyjne & 1 & ślady ognia \\
\hline 118 & $365 / 00$ & jama & Kręgi lędźwiowe & 1 & ślady ognia \\
\hline 69 & $176 / 00$ & jama & Łopatka & 1 & ślady ognia \\
\hline 118 & $365 / 00$ & jama & Kość promieniowa & 1 & ślady ognia \\
\hline 119 & $373 / 00$ & jama & Miednica & 1 & ślady ognia \\
\hline 118 & $365 / 00$ & jama & Kości śródręcza & 1 & ślady ognia \\
\hline 131 & $376 / 00$ & jama & Kość piętowa & 1 & ślady ognia \\
\hline 119 & $373 / 00$ & jama & Człon palcowy 2 & 1 & ślady ognia \\
\hline 118 & $365 / 00$ & jama & Żuchwa & 1 & ślady okopcenia \\
\hline 119 & $373 / 00$ & jama & Kość promieniowa & 1 & ślady okopcenia \\
\hline 131 & $376 / 00$ & jama & Kości śródstopia & 1 & $\begin{array}{l}\text { prawdopodobnie } \\
\text { fragment narzędzia }\end{array}$ \\
\hline \multicolumn{6}{|c|}{ Świnia } \\
\hline 119 & $373 / 00$ & jama & Kość łokciowa & 1 & ślady ognia; subadultus \\
\hline \multicolumn{6}{|c|}{ Owca/koza } \\
\hline 69 & $176 / 00$ & jama & Kość ramienna & 1 & ślady ognia \\
\hline 118 & $365 / 00$ & jama & Kość ramienna & 1 & ślady ognia \\
\hline 119 & $373 / 00$ & jama & Kość ramienna & 1 & ślady ognia \\
\hline 145 & $359 / 00$ & jama & Kość promieniowa & 1 & ślady ognia \\
\hline 119 & $373 / 00$ & jama & Kość piszczelowa & 1 & ślady ognia \\
\hline \multicolumn{6}{|c|}{ Pies } \\
\hline 118 & $365 / 00$ & jama & Kość promieniowa & 1 & $\begin{array}{l}\text { drobny fragment trzonu; } \\
\text { ślady cięć od strony } \\
\text { dogłowowej }\end{array}$ \\
\hline
\end{tabular}




\begin{tabular}{|c|c|c|c|c|c|}
\hline$\frac{\pi}{0}$ & 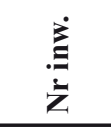 & $\begin{array}{l}\frac{\pi}{\mathscr{C}} \\
\frac{1}{E} \\
\end{array}$ & 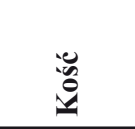 & :气̃ & 范 \\
\hline \multicolumn{6}{|c|}{ Jeleń } \\
\hline 74 & $237 / 00$ & $\begin{array}{l}\text { jama śmiet- } \\
\text { niskowa }\end{array}$ & Poroże & 1 & $\begin{array}{l}\text { drobny fragment tyki, } \\
\text { prawdopodobnie pozo- } \\
\text { stałość motyki rogowej }\end{array}$ \\
\hline 74 & $178 / 00$ & $\begin{array}{l}\text { jama śmiet- } \\
\text { niskowa }\end{array}$ & Poroże & 1 & $\begin{array}{l}\text { zrzutek, } 20 \text { fragmentów } \\
\text { tyki z pieczęcią; prawdo- } \\
\text { podobnie motyka }\end{array}$ \\
\hline 118 & $365 / 00$ & jama & Poroże & 1 & $\begin{array}{l}\text { odnoga tyki lub korony } \\
\text { z odciętym wierzchoł- } \\
\text { kiem ze śladami obróbki } \\
\text { i pracy }\end{array}$ \\
\hline 118 & $365 / 00$ & jama & Poroże & 1 & $\begin{array}{l}\text { odnoga tyki lub koro- } \\
\text { ny ze śladami obróbki } \\
\text { i pracy }\end{array}$ \\
\hline 119 & $373 / 00$ & jama & Poroże & 1 & $\begin{array}{l}\text { fragment jednej z od- } \\
\text { nóg tyki lub korony } \\
\text { ze śladami obróbki } \\
\text { i pracy - narzędzie }\end{array}$ \\
\hline 119 & $373 / 00$ & jama & Poroże & 1 & $\begin{array}{l}\text { jedna z odnóg tyki lub } \\
\text { korony ze śladami obrób- } \\
\text { ki oraz pracy }\end{array}$ \\
\hline 119 & $373 / 00$ & jama & Poroże & 1 & $\begin{array}{l}\text { zrzutek; ślady obrób- } \\
\text { ki - odcięcie uperlenia } \\
\text { róży; fragment motyki } \\
\text { rogowej }\end{array}$ \\
\hline 79 & $179 / 00$ & jama & Poroże & 1 & fragment tyki \\
\hline 74 & $237 / 00$ & $\begin{array}{c}\text { jama śmiet- } \\
\text { niskowa }\end{array}$ & Poroże & 1 & zrzutek \\
\hline 119 & $373 / 00$ & jama & Poroże & 4 & ślady ognia \\
\hline \multicolumn{6}{|c|}{ Łoś } \\
\hline 119 & $373 / 00$ & jama & Poroże & 1 & $\begin{array}{l}\text { jedna z odnóg tyki lub } \\
\text { korony; ślady obróbki; } \\
\text { fragment motyki? }\end{array}$ \\
\hline \multicolumn{6}{|c|}{ Żółw błotny } \\
\hline 74 & $237 / 00$ & $\begin{array}{l}\text { jama śmiet- } \\
\text { niskowa }\end{array}$ & karapaks & 2 & - \\
\hline \multicolumn{6}{|c|}{ Nierozpoznane } \\
\hline 119 & $373 / 00$ & jama & $\mathrm{N}$ & 1 & $\begin{array}{l}\text { uszkodzona płytka } \\
\text { kościana prawdopo- } \\
\text { dobnie o kształcie } \\
\text { wrzecionowatym }\end{array}$ \\
\hline 119 & $373 / 00$ & jama & $\mathrm{N}$ & 1 & $\begin{array}{l}\text { uszkodzona płytka ko- } \\
\text { ściana prawdopodobnie } \\
\text { o kształcie wrzecionowa- } \\
\text { tym; żebro bydła? }\end{array}$ \\
\hline
\end{tabular}




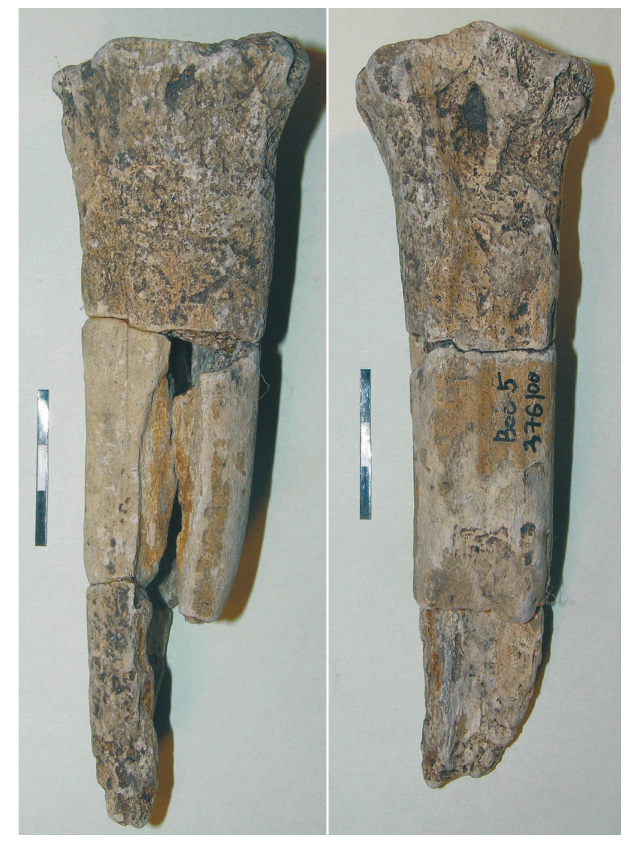

Ryc. 10. Bocień, gm. Chełmża, stanowisko 5. Bydło (Bos primigenius f. taurus) - kość śródstopia, uszkodzone dłuto? (obiekt 131); a: widok od strony bocznej, b: widok od strony doogonowej (fot. D. Makowiecki)

Fig. 10. Bocień, Chełmża commune, site 5. Cattle (Bos primigenius f. taurus) - metatarsal, a damaged chisel? (feature 131); a: lateral view, b: caudal view (phot. by D. Makowiecki)

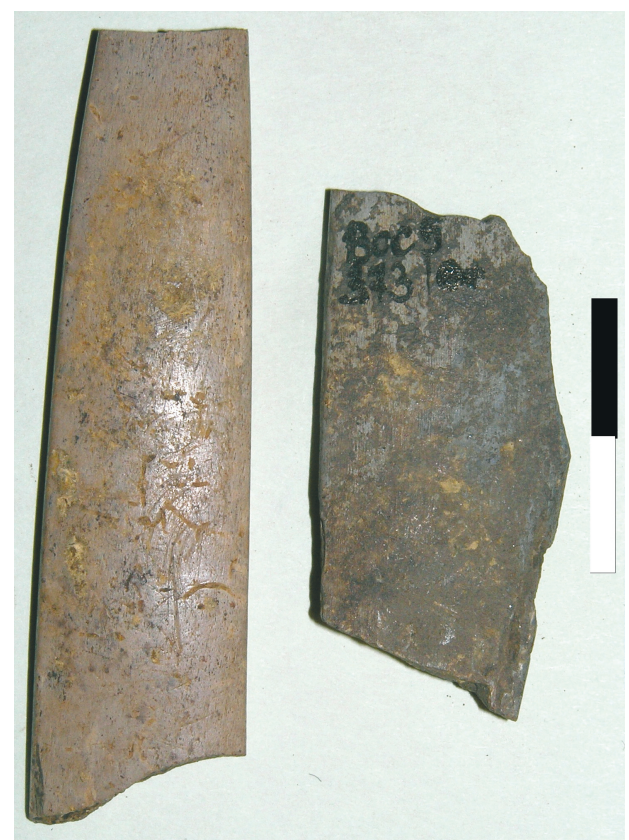

Ryc. 11. Bocień, gm. Chełmża, stanowisko 5. Płytki kościane-obiekt 119 (rys. D. Makowiecki)

Fig. 11. Bocień, Chełmża commune, site 5. Bone plates - feature 119 (phot. by D. Makowiecki) 
Tabela 8. Bocień, gm. Chełmża, stanowisko 5. Kultura ceramiki wstęgowej rytej. Bydło (Bos primigenius f. taurus) i tur (Bos primigenius Boj. 1827). Obserwacje osteometryczne i wysokość w kłębie

\begin{tabular}{|c|c|c|c|c|c|c|}
\hline & $\mathbf{L}$ & B & & & Forma & Obiekt \\
\hline \multirow{2}{*}{$\begin{array}{l}\text { Ząb dolny } \mathrm{M}_{3} \\
\left(\text { Dens inferior } \mathrm{M}_{3}\right)\end{array}$} & L: 38,8 & B: 13 & & & bydło & 119 \\
\hline & L: 43,8 & B: 16 & & & tur/bydło & 119 \\
\hline \multirow{2}{*}{ Łopatka (Scapula) } & SLC: 71,8 & GLP: 86 & & & tur/bydło & 74 \\
\hline & 0 & 86,8 & & & tur/bydło & 79 \\
\hline $\begin{array}{l}\text { Kość ramienna } \\
\text { (Humerus) }\end{array}$ & Bd: 115,2 & BT: 101,4 & & & tur & 119 \\
\hline \multirow{2}{*}{$\begin{array}{l}\text { Kość promienio- } \\
\text { wa (Radius) }\end{array}$} & Bp: 89,8 & & & & $\begin{array}{l}\text { tur/bydło } \\
\text { turze }\end{array}$ & 74 \\
\hline & Bp: 90,8 & & & & $\begin{array}{l}\text { tur/bydło } \\
\text { turze }\end{array}$ & 119 \\
\hline \multirow{2}{*}{$\begin{array}{l}\text { Kości śródręcza } \\
\text { (Metacarpus) }\end{array}$} & GL: 215,5 & Bd: 69 & WH: 131,9 & & bydło turze & 119 \\
\hline & 0 & Bp: 65,2 & & & bydło turze & 74 \\
\hline $\begin{array}{l}\text { Kości śródstopia } \\
\text { (Metatarsus) }\end{array}$ & 0 & Bp: 51,8 & & & bydło turze & 74 \\
\hline \multirow{2}{*}{$\begin{array}{l}\text { Kość skokowa } \\
\text { (Talus) }\end{array}$} & GLl: 82,8 & GLm: 76,1 & Bd: 55,1 & WH: 151,5 & tur & 119 \\
\hline & 78,7 & 71,6 & 52 & 144 & tur/bydło? & 74 \\
\hline $\begin{array}{l}\text { Człon palcowy } \\
\text { bliższy (Phalanx } \\
\text { proximalis) }\end{array}$ & Glpe: 63 & & & & bydło turze & 119 \\
\hline \multirow{2}{*}{$\begin{array}{l}\text { Człon palcowy } \\
\text { środkowy (Pha- } \\
\text { lanx media) }\end{array}$} & GL: 42 & & & & tur/bydło & 119 \\
\hline & 42,2 & & & & tur/bydło & 79 \\
\hline
\end{tabular}

Tabela 9. Bocień, gm. Chełmża, stanowisko 5. Kultura ceramiki wstęgowej rytej. Koń (Equus ferus silvestris) - człon palcowy bliższy przedni (Phalanx proximalis anterior)

\begin{tabular}{|c|c|c|c|c|c|}
\hline GL & Bp & SD & Bd & WH & Obiekt \\
\hline 82,9 & 56,3 & 36,5 & 46,7 & 129,1 & 60 \\
\hline
\end{tabular}

na podstawie obecności poroży ze śladami wskazującymi na intencjonalną modyfikację pierwotnych kształtów oraz kości będących przedmiotami użytkowymi (ryc. 7 i 8).

Biorąc pod uwage skład gatunkowy udokumentowanej fauny można postawić tezę o uzyskiwaniu surowców pochodzenia zwierzęcego poprzez hodowlę ssaków domowych, polowania i chwytanie żółwi. Wśród wymienionych rodzajów aktywności gospodarczej, pierwsza z nich był najważniejsza, a podstawowy gatunek stanowiło bydło. Można też przypuszczać, że należało ono do najliczniejszych komponentów domowego pogłowia. Jednym 
z ważniejszych celów hodowli tych zwierząt, prawdopodobnie pierwszoplanowym, było uzyskiwanie mięsa, które przyrządzano do spożycia przez obróbkę termiczną polegającą między innymi na pieczeniu porcji nad ogniem. Obok mięsa uzyskiwano szpik kostny, być może spożywany po uprzedniej obróbce termicznej na ogniu, na co wskazują ślady okopceń na trzonach niektórych kości, w tym śródręcza, gdzie udział mięśni jest znikomy w stosunku do objętości szpiku w kanale szpikowym.

Wskazane sposoby poprawiania wartości smakowych i odżywczych produktów spożywczych pochodzenia zwierzęcego były rozpowszechnione także u ludności KCWR zamieszkującej Kujawy. Przesłanek do takich stwierdzeń dostarczyły analizy tafonomiczne materiałów kostnych przeprowadzone przez A. Marciniaka (2005). Egzemplarze kości śródręcza i śródstopia ze śladami łamania trzonów w celu dostania się do szpiku oraz jego pieczenia znane są na przykład z Zagajewic (ryc. 12); na ich trzonach stwierdzono takie same ślady jak w materiale z Bocienia - przebarwienia powstające podczas pieczenia (Grygiel 2004; Marciniak 2005).

Sumaryczny rozkład anatomiczny szczątków bydła wskazuje, że odsetek żeber oraz elementów głowy jest najwyższy, można by zatem sądzić, że odzwierciedla to określone upodobania kulinarne ludności KCWR. Jednak wnikając w morfologię i relacje liczbowe elementów tworzących kościec nasuwa się inne wyjaśnienie powyższych obserwacji. Otóż, ze względu na wydłużony kształt oraz stosunkowo niewielką grubość, żebra podlegały kawałkowaniu podczas intencjonalnego porcjowania tuszy, a także dalszej fragmentacji w wyniku procesów podepozycyjnych. Mimo, że wiele z nich należy do jednego egzemplarza, to jednak duży stopień zniszczenia znacznie ogranicza, a najczęściej uniemożliwia wskazanie, które należały do jednej jednostki anatomicznej. $\mathrm{Z}$ powyższych względów w zbadanym materiale udział tych kości w stosunku do pozostałych elementów szkieletu (kręgów, kości długich) jest mocno zawyżony. Dodatkowym czynnikiem mogącym powodować zawyżony udział żeber, jest także stosunkowo duża ich liczba (26) w szkielecie. Z kolei wysoki udział szczątków pochodzących z głowy jest w dużym stopniu pochodną cienkiej konstrukcji tkanki kostnej czaszki, co powoduje łatwą jej fragmentację już na etapie rozbijania w celu uzyskania mięsa i mózgu. Jednak cechy morfologiczne są na tyle dystynktywne, że nawet małe kawałki kości nadają się do oznaczeń anatomicznych i gatunkowych. Mając na uwadze powyższe refleksje, na podstawie rozkładu anatomicznego, rozpatrywanego w skali całej osady, bardziej zasadny jest wniosek o wykorzystywaniu do celów konsumpcyjnych elementów pochodzących z różnych 


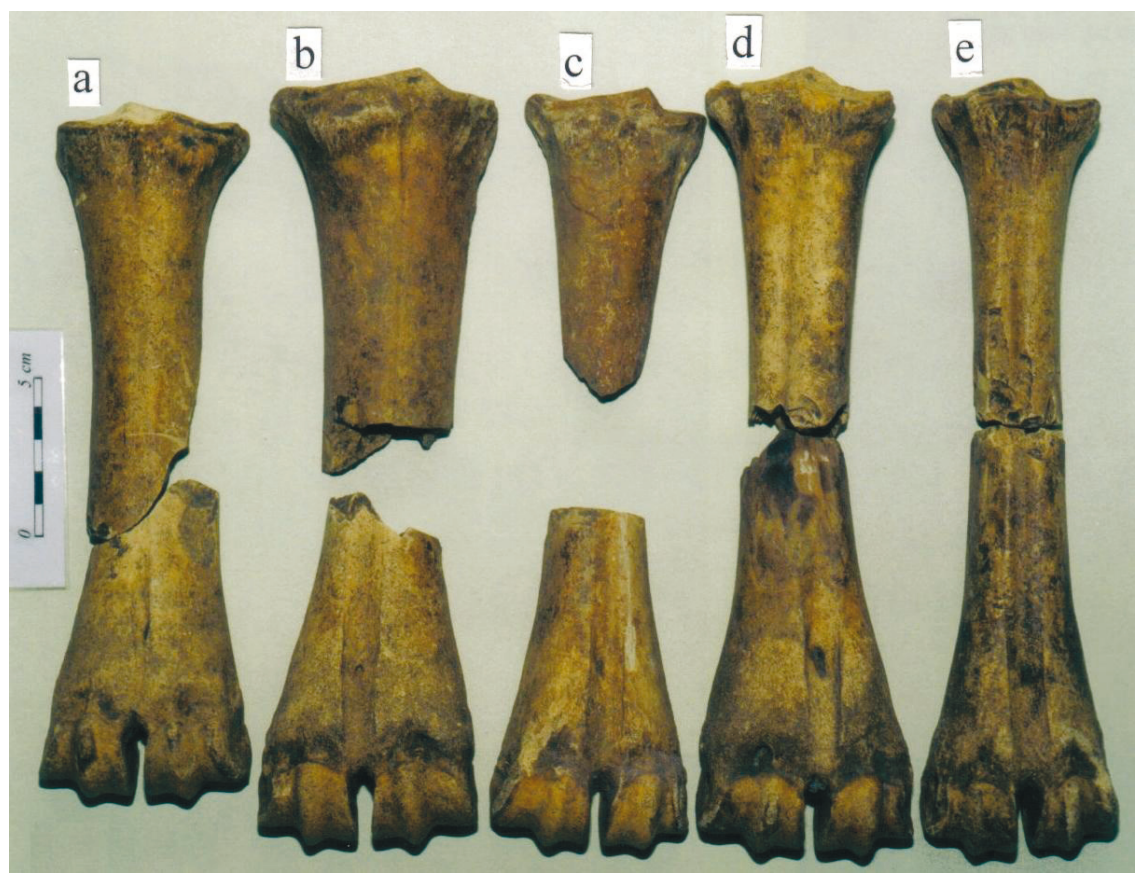

Ryc. 12. Zagajewice, gm. Osięciny, stanowisko 1. Osada ludności kultury ceramiki wstęgowej rytej. Bydło (Bos primigenius f. taurus); a, c: kość śródręcza; b, d, e: kości śródstopia - egzemplarze z widocznymi, intencjonalnymi złamaniami, powstałymi na skutek pozyskiwania szpiku (fot. D. Makowiecki)

Ryc. 12. Zagajewice, Osięciny commune, site 1. Linear band pottery culture settlement. Cattle (Bos primigenius f. taurus): a, c: metacarpal; b, d, e: metatarsals - specimens with traces of cracking arisen during marrow extraction (phot. by D. Makowiecki)

części tusz zwierzęcych, bez jakichkolwiek preferencji. Te łatwiej uchwycić na bazie rozkładów anatomicznych rozpatrywanych przestrzennie, czego dobrym przykładem są rozkłady anatomiczne u bydła, wskazujące wyraźnie na zoologiczną strefowość osady. Biorąc pod uwagę stwierdzenia o antropogenicznej genezie zbiorów kostnych, można przypuszczać, że odnotowana strefowość jest efektem pewnych zachowań kulturowych związanych z ubojem zwierząt, rozbiorem zasadniczym tuszy i jej porcjowaniem, a w końcu z konsumpcją mięsa, tłuszczu oraz szpiku i mózgu. O tym, że w południowej strefie osady wymienione czynności odbywały się częściej niż w okolicach domostwa I, mogą świadczyć odkryte inwentarze krzemienne, wśród których 30\% stanowią narzędzia służące do obróbki mięsa, skóry i kości/poroża. W strefie obu domostw takie funkcje określono jedynie w stosunku do $16 \%$ narzędzi (Małecka-Kukawka w niniejszym tomie). 
Mleko, jako naturalna wydzielina gruczołu mlekowego krów, mogło nie być tak istotnym produktem spożywczym dla ludności osady w Bocieniu, skoro sporą część stada bydła, co najmniej połowę, kierowano na rzeź zanim skończyła pełny rozwój anatomiczny, chyba że osobnikami w wieku adultus byłyby głównie krowy. Jednak tego ostatniego założenia, w świetle przesłanek źródłowych uzyskanych z Bocienia, nie można ani odrzucić ani potwierdzić. Natomiast na podstawie rozkładu płci w stadach dorosłego bydła (adultus) hodowanych przez ludności KCWR na Niżu Środkowoeuropejskiem, gdzie udział krów i byków był niemal jednakowy (Benecke 1994, s. 130), można przypuszczać, że taka sama sytuacja miała miejsce na ziemi chełmińskiej. Oznaczałoby to więc, że konsekwencją takich relacji w stadzie bydła był mięsny kierunek jego użytkowania i uzyskiwanie innych technologicznych, tzw. ubocznych surowców pochodzenia zwierzęcego. Można przypuszczać, że część mleka pochodziła od kóz, o czym świadczy odkryty w Bocieniu możdżeń samicy tego gatunku.

W porównaniu do bydła, owcy i kozy nożna przypisywać mniejsze znaczenie, jednak ich stada prawdopodobnie stanowiły liczniejszy komponent pogłowia niż świnia. Tak więc, ludność KCWR w hodowli zwierząt ukierunkowana była na utrzymywanie przeżuwaczy, gatunków nadających się do pasterstwa i wymagających biotopów zawierających roślinność trawiastą. Taka struktura pogłowia oraz znaczenie wspomnianych zwierząt było charakterystyczne dla grup KCWR zamieszkujących strefę Niżu Polskiego, co najlepiej udokumentowano na Kujawach (Sobociński 1985; Sobociński, Makowiecki 1990; Grygiel 2004). Także na ziemi chełmińskiej ludność tej kultury, zamieszkująca osadę w Stolnie (II faza rozwoju KCWR), preferowała hodowlę przeżuwaczy, jednak tam relacje w strukturze pogłowia ssaków domowych były odmienne niż w Bocieniu, bowiem udział zidentyfikowanych kości bydła wynosił 44,3\%, a owcy/kozy 47,5\% (Makowiecki 1987).

Kolejnym gatunkiem domowym hodowanym przez ludność osady był pies, którego użyteczność w nadzorowaniu pasących się stad przeżuwaczy jest oczywista. Jednak poza samym faktem jego obecności w pogłowiu zwierząt gospodarskich, należy także zwrócić uwagę na możliwość użytkowania pośmiertnego psa w kontekście odnotowanych na kości promieniowej negatywów cięć, takich jak na szczątkach bydła (ryc. 5, 6). Ich powstanie należałoby łączyć z przygotowywaniem tuszy zwierzęcia do konsumpcji. Przesłankami do takiego twierdzenia w przypadku materiałów faunistycznych ze Stolna było znalezienie spalonych zębów psa (Makowiecki 1987). 
Wiek osobniczy (śmierci) bydła wskazuje, że surowce spożywcze i technologiczne poubojowe pochodziły ze sztuk o zróżnicowanej masie ciała. Uzyskiwano mięso z osobników młodych i starych, a więc o odmiennych walorach jakościowych i smakowych. Wiek osobniczy bydła, określony w skali miesięcy, który można przełożyć na porę (sezon) uboju w trakcie roku (Makowiecki 2001), świadczy o kierowaniu na rzeź zwierząt w różnych momentach cyklu rocznego. Bydło zabijano więc w okresie pastwiskowym (np. cielęta 4-6 miesięcy) i na jego początku (sztuki 25-28 miesięcy). Niestety, brak dostatecznej liczby obserwacji nie pozwolił na wskazanie poziomu ubojów dla wymienionych okresów. Dopełnieniem, aczkolwiek też w niewielkim zakresie, powyższej interpretacji są dwie obserwacje uzyskane dla świni i małych przeżuwaczy, według których sztuki tych gatunków kierowano na rzeź zarówno w okresie pastwiskowym, jak i poza nim.

Obecność szczątków ssaków dzikich skłania do wnioskowania o pozyskiwaniu surowców zwierzęcych także w wyniku polowania. Powszechnie przyjmuje się, że ta sfera aktywności gospodarczej miała wyraźnie mniejsze znaczenie u ludów rolniczych niż hodowla ssaków domowych. Niski odsetek pozostałości wymienionej grupy zwierząt może więc być uznany za potwierdzenie powyższej tezy. W przypadku ludności zamieszkującej zbadaną osadę jest to tym bardziej uzasadnione, że identyfikacji trzech gatunków jeleniowatych dokonano na podstawie poroża, na dodatek części egzemplarzy będących tzw. zrzutkami. Nie można zatem traktować ich jako pozostałości pokonsumpcyjne, uzyskane w wyniku polowania. Stanowią one natomiast podstawę do stwierdzenia, że ludność KCWR doceniała znaczenie poroża w produkcji narzędzi, lecz wykorzystywany do tego celu surowiec częściej pozyskiwano zbierając wiosną zrzucone wieńce jeleni i porostki saren czy łopaty łosi niż polując na zwierzynę. Podobną sytuację odnotowano w materiałach ze Stolna - osiem zidentyfikowanych szczątków jelenia było porożem, w tym na dwóch egzemplarzach stwierdzono ślady obróbki, a jeden uznano za fragment motyki (Makowiecki 1987).

W przypadku pozostałości kostnych konia trudno, na podstawie badań makroskopowych, wskazać formę dziką bądź domową. W tej kwestii można jedynie odwołać się do obecnego stanu wiedzy na temat historii tego zwierzęcia i pojawienia się jego formy domowej. Powszechnie sądzi się, że w Europie Środkowej, w okresie rozwoju KCWR, koń nie był udomowiony, zatem znajdowane w zbiorach tej kultury szczątki pochodzą od osobnika dzikiego, który był przedmiotem polowań (np. Benecke 1994; 2006). Takie pochodzenie należy także przypisać kości tego gatunku zidentyfikowanej w Bocieniu. 
Pod względem wysokości w kłębie był to osobnik mieszczący się w zakresie wielkościowym określonym dla koni z obszaru obecnych Niemiec, między 120 a $135 \mathrm{~cm}$ (Benecke 2006). W świetle danych uzyskanych dla Kujaw (Sobociński, Makowiecki 1990), w strefie nad środkową Notecią (Makowiecki 2009) oraz dla Bocienia można stwierdzić, że polowania na ten gatunek nie należały do częstych. Podobne wnioski nasuwają się w odniesieniu do nielicznych w analizowanym zbiorze kości tura. Taki sposób zachowań w eksploatacji naturalnych zasobów fauny wolno żyjącej można uznać za efekt zachowań gospodarczych obowiązujących w społecznościach rolniczych, do których należała grupa ludności zamieszkującej osadę w Bocieniu.

Do zwierząt wolno żyjących, użytkowanych konsumpcyjnie, należy zaliczyć żółwia błotnego. Gatunek ten w klimacie atlantyckim (około 6400-3100 BC), a więc także we wczesnym neolicie, podobnie jak inne zwierzęta ciepłolubne, znalazł w strefie Niżu Polskiego sprzyjające warunki do zadomowienia się. Był to okres optimum klimatycznego, w którym średnia temperatura lipca wynosiła około $21^{\circ} \mathrm{C}$. W niektórych regionach gatunek ten tworzył liczne populacje, tak przynajmniej można sądzić na podstawie pozostałości zbiorów faunistycznych, odkrytych nad Drwęcą w miejscowości Mszano (stanowisko 2). W odkrytym tam obozowisku/osadzie łowców, rybaków i zbieraczy, na blisko 2000 rozpoznanych pozostałości zwierzęcych, resztki żółwia stanowiły 41\% (Makowiecki, Rybacki 2001; Makowiecki 2003, s. 58). Biorąc pod uwagę współczesną wiedzę na temat optymalnych warunków siedliskowych dla bytowania tego gatunku (Głowaciński 1992), można sądzić, że w okolicy, poza położonym w pobliżu obozowiska/osady jeziorem Wieczno, znajdowały się niewielkie zbiorniki wodne, obszary bagienne lub wolno płynące cieki. Najkorzystniejszym momentem do chwytania żółwi był okres od maja do połowy czerwca lub lipca, kiedy to w wilgotnym piasku samice składały jaja.

Traktując obecność szczątków ssaków dzikich jako podstawę do refleksji o zachowaniach gospodarczych warto też zwrócić uwagę na ich znaczenie w rekonstruowaniu środowiska przyrodniczego (np. Makowiecki 2001; 2008; 2010; Makowiecki, Stach 2007), podobnie jak uczyniono to w przypadku żółwia błotnego. Można stwierdzić, odwołując się do cytowanych publikacji, że obszary wokół osady w Bocieniu otaczały lasy, czego wyznacznikiem byłyby jeleń i tur. O występowaniu obszarów podmokłych, porośniętych drzewami liściastymi, świadczy łoś. Sarny natomiast wykorzystywały pogranicze obszarów leśnych i otwartych, podobnie jak przeżuwacze domowe, korzystały $\mathrm{z}$ tych samych areałów trawiastych i miejsc, które stawały się rżyskami po zebraniu upraw roślinnych. 
Powyższy opis skłania do jeszcze jednej refleksji dotyczącej czynników warunkujących zachowania gospodarcze. $Z$ przeprowadzonych analiz wyni$\mathrm{ka}$, że walory środowiska przyrodniczego były wystarczające do praktykowania łowiectwa. Kwestią otwartą pozostaje jedynie określenie, jak wielkie były zasoby zwierzyny dzikiej i w jakim stopniu mogły wpływać na skalę uprawiania tej gałęzi gospodarki przez ludność zamieszkującą osadę w Bocieniu. Takie rozważania wykraczaja jednak poza ramy merytoryczne niniejszego artykułu, nie znajdują też należytych podstaw źródłowych i przesłanek teoretycznych. Dlatego też na obecnym etapie badań bardziej uzasadnione wydaje się wyjaśnienie małej roli łowiectwa, wynikającej bardziej z rolniczej tradycji kulturowej ludności KCWR, niż z korzystnych walorów środowiskowych, mających wpływ na wybór kierunków gospodarowania zasobami fauny.

Bydło użytkowane przez mieszkańców osady w Bocieniu należało do formy turzej (Bos primigenius), wielkością najczęściej odpowiadało osobnikom z Kujaw (Sobociński 1985) oraz z Niemiec (Döhle 1994). Wartość pomiarów części kości mieści się w tzw. strefie transgresji między turem a bydłem. W literaturze przedmiotu uważa się za nią wartości skrajne, odpowiadające największym kościom samców bydła i najmniejszym kościom samic tura. Taki rozkład jest efektem dymorfizmu płciowego oraz zmniejszenia się rozmiarów ciała formy domowej przy zachowanych relacjach wielkościowych między większymi samcami i mniejszymi od nich samicami, tak jak to było u tura. Bardzo długo uznawano, że w strefie transgresji mieszczą się kości form powstałych w wyniku krzyżowania się bydła domowego z turem (Benecke 1994, s. 48 i nn.; tam dalsza literatura); traktowano to jako przesłankę do stawiania tezy o procesach lokalnych domestykacji w środkowej Europie (ostatnio A. Lasota-Moskalewska 2005). Dopiero w początku lat 90. ubiegłego stulecia, w oparciu o dane metryczne poddane odpowiedniej analizie statystycznej, N. Benecke uznał, że bydło hodowane przez ludność KCWR odznaczało się dużym stopniem udomowienia, a miejscowa populacja turów nie miała znaczenia, lub tylko niewielkie, na powstanie populacji bydła domowego (Benecke 1994, s. 50). Wyniki badań genetycznych (mDNA) kości bydła $z$ osad odkrytych na obszarze Niemiec, datowanych na wczesne fazy kultury ceramiki wstęgowej, wykluczyły możliwość lokalnych udomowień (Bolongino i in. 2003). Tak więc w konkluzji należy stwierdzić, że ludność kultury ceramiki wstęgowej rytej obok owiec i kóz, przyprowadziła na obszar Niżu Środkowoeuropejskiego także bydło i nie dokonywała niezależnych lokalnych udomowień tura. Można więc postawić hipotezę, że hodowla bydła 
przez ludność osady w Bocieniu była również jedynie wynikiem utrwalonych tradycji kulturowych. Należy jednak zdawać sobie sprawę z tego, że w weryfikacji tej hipotezy pomocne byłyby badania genetyczne (mDNA) szczątków kostnych ze zbadanej osady.

\section{Podsumowanie}

Na koniec należy podkreślić, że poza materiałami ze Stolna, zbadane szczątki kostne, są drugim tak licznym zbiorem dokumentującym użytkowanie zwierząt przez społeczności KCWR na ziemi chełmińskiej. Z przeprowadzonych badań wynika, że ludność zamieszkująca osadę w swoich zachowaniach gospodarczych nawiązywała do reguł kulturowych obowiązujących na szerszym obszarze, na przykład na Kujawach. W wytwarzaniu pożywienia pochodzenia zwierzęcego podstawę stanowiła hodowla, natomiast eksploatacja naturalnych zasobów fauny, na przykład turów, jeleni, łosi, saren i dzikich koni (prawdopodobnie tarpana) była wyraźnie mniejsza. Konkluzję tę uzasadniają nie tylko analizy archeozoologiczne, lecz także traseologiczne, wykonane dla inwentarzy krzemiennych odkrytych w osadach ludności KCWR na ziemi chełmińskiej. Na ich podstawie uznano, że ostrza broni miotanej (groty strzał) stanowiły minimalny udział $\mathrm{w}$ zbiorach narzędzi funkcjonalnych, w tym związanych z obróbką surowców zwierzęcych, takich jak mięso, skóry, poroże/kości (Małecka-Kukawka 2001, s. 128). Należy dodać, że w Bocieniu wśród 120 narzędzi krzemiennych tylko jedno uznano za grot strzały (Małecka-Kukawka w niniejszym tomie).

Wyniki analiz archeozoologicznych uzyskane dla zbiorów z Bocienia i Stolna są odmienne, co mogłoby świadczyć o stosowaniu przez ludność tej samej kultury zamieszkującej ziemię chełmińską swoistych strategii wytwarzania surowców zwierzęcych. Jednak przy takiej konkluzji, trzeba mieć na uwadze fakt, że szczątki kostne ze Stolna pochodzą praktycznie z jednego obiektu będącego paleniskiem (Sosnowski 1990; Makowiecki 2003, s. 73), a nie z wielu położonych w różnych funkcjonalnych koncentracjach, tak jak w Bocieniu.

Niewątpliwa wartość poznawcza zbadanych materiałów polega na tym, że dane archeozoologiczne można traktować jako niezależne kryteria, które posłużyły do wyodrębnienia stref przestrzenno-funkcjonalnych, podobnie jak dane archeologiczne. Na koniec warto też podkreślić, że źródła archeozoologiczne z Bocienia jako pierwsze na ziemi chełmińskiej dostarczyły podstaw do analizy wieku osobniczego bydła oraz jego form morfologicznych. 


\section{LITERATURA}

Benecke N.

1994 Archäozoologische Studien zur Entwicklung der Haustierhaltung in Mitteleuropa und Südskandinavien von den Anfängen bis zum ausgehenden Mittelalter, Berlin.

Binford L. R.

1981 Bones. Ancient men and modern myths, Orlando.

Bollongino R., Burger J., Alt K. W.

2003 Import oder sekundäre Domestikation? Der Ursprung der europäischen Hausrinder im Spiegel molekulargenetischer Analysen an neolithishen, Beiträge zur Archäozoologie und Prähistorischen Anthropologie, t. 4, s. 211-217.

Calkin V. I.

1960 Izmenčivost metapodij i jejo značenje dlja izučenja krupnogo rogotogo skota drevnosti, Bjulleten Obščestva Ispytatelej Prirody, Otdel Biologii, t. 65 , z. 1, s. 109-126.

1970 Drevnejše domašnje životnye vostočnoj Evropy, Moskva.

Degerbøl M., Fredskild B.

1970 The Urus (Bos primigenius Bojanus) and Neolithic domesticated cattle (Bos taurus domesticus Linné) in Denmark, with a revision of Bos-remains from the kitchen middens. Zoological and Palynological Investi-

Döhle, H-J. gations, København.

1994 Die linienbandkeramischen Tierknochen von Eilsleben, Bördekreis. Ein Beitrag zur neolithischen Haustierhaltung und Jagd in Mitteleuropa, Halle (Saale).

Driesch A.

1976 A guide to the measurement of animal bones from archaeological sites, Harvard.

Gedymin T.

1965 Tur (Bos primigenius Bojanus 1827) na ziemiach Wielkopolski i Kujaw. Studium materiału kostnego wykopaliskowego, Roczniki Wyższej

Grygiel R.

Szkoły Rolniczej w Poznaniu, t. 25, s. 21-37.

2004 Neolit i poczatki epoki brazu w rejonie Brześcia Kujawskiego i Osłonek, t. 1, Wczesny neolit i kultura ceramiki wstęgowej rytej, Łódź.

Kobryń H., Lasota-Moskalewska A.

1989 Certain osteometric differences between the aurochs and domestic cattle, Acta Theriologica, t. 34, z. 4, s. 67-82.

Komosa M., Godynicki S., Stanisławski D.

1999 Szacowanie wielkości konia na podstawie zwiazku cech metrycznych eksterieru z obwodowymi odcinkami kośćca kończyn, [w:] Szczatki zwierzęce jako źródło badań nad zróżnicowaniem poziomów życia 
materialnego i kulturowego ludzi w różnych okresach dziejowych, Wrocław, s. 69-75.

Kukawka S.

1997 Na rubieży środkowoeuropejskiego świata wczesnorolniczego, Toruń.

Kukawka S., Małecka-Kukawka J., Wawrzykowska B.

2002 Wczesny i środkowy neolit na ziemi chetmińskiej, [w:] Archeologia toruńska. Historia i teraźniejszość, red. B. Wawrzykowska, Toruń, s. $91-107$.

Lasota-Moskalewska A.

2005 Zwierzęta udomowione w dziejach ludzkości, Warszawa.

Lasota-Moskalewska A., Kobryń H.

1990 The size of aurochs skeletons from Europe and Asia in the period from

Neolithic to the Middle Ages, Acta Theriologica, t. 35, z. 1-2, s. 89-109.

Makowiecki D.

1987 Źródła archeozoologiczne z epoki neolitu i poczqtku epoki brazu z ziemi chetmińskiej, [w:] Neolit i poczatki epoki brazu na ziemi chetmińskiej, red. T. Wiślański, Toruń, s. 259-273.

2001 Hodowla oraz użytkowanie zwierzqt na Ostrowie Lednickim w średniowieczu, Studium archeozoologiczne, Biblioteka Studiów Lednickich, t. 6, Poznań.

2003 Historia ryb i rybołówstwa $w$ holocenie na Niżu Polskim w świetle badań archeoichtiologicznych, Poznań.

2008 Badania archeozoologiczne w studiach nad paleośrodowiskiem człowieka, [w:] Człowiek i środowisko przyrodnicze we wczesnym średniowieczu $w$ świetle badań interdyscyplinarnych, red. W. Chudziak, Toruń, s. $123-137$.

2010 Wczesnośredniowieczna gospodarka zwierzętami i socjotopografia in Culmine na Pomorzu Nadwiślańskim, Mons Sancti Laurentii, t. 6, Toruń.

Makowiecki D., Godynicki S.

1993 Zwierzęce źródta kostne do poznania gospodarki zwierzętami społeczeństw prahistorycznych i średniowiecznych ziemi chetmińskiej, [w:] Badania archeologiczne ośrodka toruńskiego w latach 1989-1992, red. J. Chudziakowa, Toruń, s. 111-117.

Makowiecki D., Rybacki M.

2001 Archeologiczne znaleziska szczatków żólwia i jego znaczenie u społeczeństw prahistorycznych oraz wczesnohistorycznych na Nizu Polskim, [w:] Źółw błotny, red. B. Najbar, S. Mikrus, Świebodzin, s. 97-102.

Makowiecki D., Stach A.

2007 Ssaki wolno żyjace $w$ holocenie Polski - aspekty środowiskowe i gospodarcze, [w:] Studia interdyscyplinarne nad środowiskiem i kultura w Polsce, red. M. Makohonienko, D. Makowiecki, Z. Kurnatowska, Środowisko - Człowiek - Cywilizacja, t. 1, Poznań, s. 155-170.

Małecka-Kukawka J.

1994 „Gospodarka” surowcami krzemiennymi wśród społeczności wczesnorolniczych ziemi chetmińskiej z perspektywy teorii wymiany społecznej, 
[w:] Neolit i poczqtki epoki brqzu na ziemi chetmińskiej, red. L. Czerniak, Grudziądz, s. 37-50.

2001 Między forma a funkcja, Traseologia neolitycznych zabytków krzemiennych z ziemi chetmińskiej, Torun.

Marciniak A.

2005 Placing animals in the Neolithic: Social zooarchaeology of prehistoric farming, London.

2006 From animals and food in space to bones in context. Social zooarchaeology of the Neolithic farming communities, [w:] Deconstructing context. A critical approach to archaeological practice, red. D. Papaconsantinou, Oxford, s. 34-49.

2008 Analiza archeozoologiczna i tafonomiczna zwierzęcych szczatków kostnych z osady z młodszego okresu przedrzymskiego w Eękach Górnych, stan. 1, gm. Krzyżanów, [w:] Osada wielokulturowa w Łękach Górnych, stan. 1, gm. Krzyżanów, red. L. Czerniak, J. Gąssowski, Via Archaeological Pultuskiensis, t. 2, Pułtusk, s. 233-246.

Moździoch S.

1999 Socjotopografia grodu wczesnośredniowiecznego w Bytomiu Odrzańskim w świetle analizy zwierzęcych szczatków kostnych, [w:] Szczatki zwierzęce jako źródło badań nad zróżnicowaniem poziomów życia materialnego i kulturowego ludzi w różnych okresach dziejowych, Wrocław, s. 91-103.

2002 Castrum Munitissimum Bytom. Lokalny ośrodek władzy w państwie wczesnopiastowskim, Warszawa.

Opracowanie

2006 Opracowanie wyników ratowniczych badań archeologicznych przeprowadzonych na odcinku A1 planowanej autostrady w woj. kujawsko-pomorskim (b. woj. toruńskie), Bocień, gm. Chełmża, stanowisko 5, t. 1, maszynopis w archiwum Zespołu do Badań Autostrady A1; Instytutu Archeologii UMK, Toruń.

Polska księga

1992 Polska czerwona księga zwierzat, red. Z. Głowaciński, Warszawa. Sobociński M.

1985 Szczatki kostne z osad ludności kultury ceramiki wstęgowej na Kujawach (ze studiów nad rozwojem kultur wstęgowych na Kujawach), Roczniki Akademii Rolniczej w Poznaniu, t. 164, Archeozoologia 10, s. $87-127$.

Sobociński M., Makowiecki, D.

1990 Stan badań nad źródłami archeozoologicznymi kultury amfor kulistych, [w:] Kultura amfor kulistych $w$ rejonie Kujaw, red. A. Cofta-Broniewska, Poznań, s. 177-187.

Sosnowski W.

1990 Stolno, gmina Stolno, województwo toruńskie, stanowisko 2, jama 2, [w:] Z badań nad chronologiq absolutnq stanowisk neolitycznych z ziemi chetmińskiej, red. D. Jankowska, Toruń, s. 15-19. 
Zietzschmann O., Krölling O.

1955 Lehrbuch der Entwicklungsgeschichte der Haustiere, Berlin.

\title{
ZOOARCHAEOLOGICAL DATA FOR RECOGNIZING THE ECONOMY OF LINEAR BAND POTTERY CULTURE POPULATION IN CHEŁMNO LAND, BOCIEŃ SETTLEMENT, SITE 5, CHEŁMŻA COMMUNE
}

\author{
Summary
}

During rescue excavations curried out in the Kujawsko-Pomorskie section of A1 motorway in Chełmża commune, animal bone remains were found in Bocień, site 5. The only homogenous and simultaneously the most numerous assemblage (1115 NISP) were bones collected in features of the linear band pottery culture (LBPC) - phase II and III. They were registered within the range of an space-function areas I, II and S of the settlement (fig. 1, appendix 1).

The material presented significant predomination of domestic mammals, mainly cattle, clearly smaller bones of pig, sheep/goat and dog. Wild mammals are represented by red deer, elk, roe deer and aurochs. Reptile remains belonged to European pond turtle. Teeth and head bones were the most numerous cattle elements' specimens. Some of cattle, pig, sheep/goat and dog bones bore traces of shallow and narrow pits after using blades (knives) of stone (flint). The others registered black coloring, which was the result of meat or bone marrow roasting. The collection also consisted of examples with work traces (fragments of red deer and elk antlers) and bone tools (chisel - made of metatarsal) and plates' fragments.

The excavated fauna collection became the grounds for interpretation, referring to the following questions: a) genesis of the studied fauna finds, b) significance of domestic species in manufacturing raw material of animal origin, c) strategies implemented in manufacturing raw material of animal origin, d) some features of natural environment of the settlement surrounding and e) Neolithic morphotypes of Chełmno Land animals.

Population inhabiting the settlement produced food of animal origin by breeding. Utilization of natural fauna resources, e.g. aurochs, deer, roe-deer and wild horses (probably tarpan) was clearly smaller. Animal economy was based on cattle, which belonged to aurochs like form (Bos primigenius), analogous to cattle sizes from Kuyavia and settlements of linear band pottery culture populations inhabiting the areas of present Germany. Meat and bone marrow obtained of it was prepared for consumption by roasting it in fire. Cow milk was not important food product, because at least half of herds' populations was slaughtered at juvenis and subadultus ages.

Keeping ruminants, species suitable for grazing, resulted from open grassy spaces existence. However, the settlement was also surrounded by forests, what is confirmed by red deer and aurochs presence in the material. A part of the land was soppy, grown with temporate broadleaved forests, perfect for elks existence. 
The performed exploration and analyses deliver evidence, that local population inhabiting the settlement related in their economic strategy to cultural rules obligatory in wider space, e.g. in Kuyavia.

Zooarchaeological sources from Bocien, as first in Chełmno Land delivered the grounds for analyses of cattle individual age and its morphological forms. Moreover, thanks to anatomical composition analysis we were able to indicate the settlement spatial zones, basing on observations made by the means of archaeological data.

Translated by Ewa Józefowicz

\section{ANEKSY}

Aneks 1. Bocień, gm. Chełmża, stanowisko 5. Kultura ceramiki wstęgowej rytej. Zestawienie liczbowe szczątków zwierząt według gatunków i danych stratygraficznych

\begin{tabular}{|c|c|c|c|c|c|c|c|c|c|c|c|c|c|c|c|c|}
\hline$\frac{\bar{\pi}}{\frac{\pi}{0}}$ & 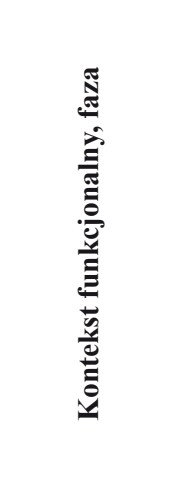 & $\frac{2}{3}$ & 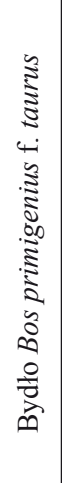 & 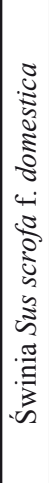 & 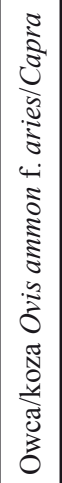 & 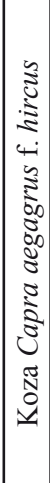 & 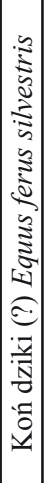 & 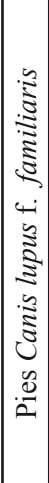 & 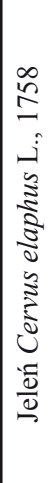 & 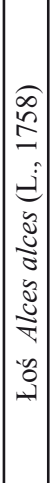 & 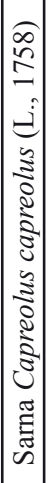 & 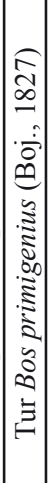 & 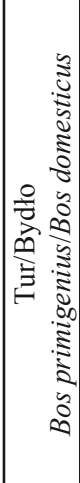 & 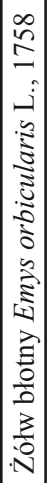 & 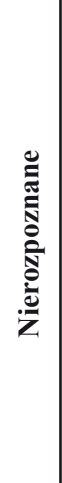 & 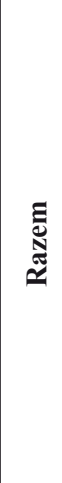 \\
\hline 117 & \multirow{4}{*}{ domostwo I } & $61 / 69 \mathrm{BC}$ & 5 & 1 & 0 & 0 & \begin{tabular}{l|l}
0 \\
\end{tabular} & 0 & 0 & 0 & 0 & 0 & 0 & \begin{tabular}{|l|}
0 \\
\end{tabular} & 7 & 13 \\
\hline 118 & & $61 / 69 \mathrm{BC}$ & 20 & 0 & 4 & 1 & \begin{tabular}{|l|}
0 \\
\end{tabular} & 1 & 2 & 0 & 0 & 0 & 0 & 0 & 30 & 58 \\
\hline 119 & & 61/69ABCD & 51 & 1 & 11 & 0 & 0 & 0 & 7 & 1 & 0 & 2 & 3 & 0 & 119 & 195 \\
\hline 152 & & $62 / 71 \mathrm{~B}$ & 0 & 0 & 0 & 0 & 0 & 0 & 0 & 0 & 0 & 0 & 0 & 0 & 5 & 5 \\
\hline \multicolumn{3}{|c|}{ Razem domostwo I, faza II } & 76 & 2 & 15 & 1 & 0 & 1 & 9 & 1 & 0 & 2 & 3 & 0 & 161 & 271 \\
\hline 93 & \multirow{5}{*}{ domostwo II } & $61 / 73 \mathrm{C}$ & 2 & 0 & 0 & 0 & 0 & 0 & 0 & 0 & 0 & 0 & 0 & 0 & 0 & 2 \\
\hline 102 & & $60 / 73 \mathrm{~B}$ & 1 & 0 & 0 & 0 & 0 & 0 & 0 & 0 & 0 & 0 & 0 & 0 & 0 & 1 \\
\hline 150 & & $61 / 72 \mathrm{CD}$ & 0 & 0 & 0 & 0 & 0 & 0 & 0 & 0 & 0 & 0 & 0 & 0 & 1 & 1 \\
\hline 165 & & $61 / 72 \mathrm{~B}$ & 8 & 0 & 0 & 0 & 0 & 0 & 0 & 0 & 0 & 0 & 0 & 0 & 2 & 10 \\
\hline 166 & & $61 / 72 \mathrm{C}$ & 4 & 0 & 0 & 0 & 0 & 0 & 0 & 0 & 0 & 0 & 0 & 0 & 2 & 6 \\
\hline \multicolumn{3}{|c|}{ Razem domostwo II, faza II } & 167 & 4 & 30 & 2 & 0 & 2 & 18 & 2 & 0 & 4 & 6 & 0 & 327 & 562 \\
\hline 60 & \multirow{4}{*}{ skupisko S } & $57 / 70 \mathrm{BC}$ & 3 & 0 & 0 & 0 & 1 & 0 & 0 & 0 & 0 & 0 & 0 & 0 & 4 & 8 \\
\hline 67 & & 54/71B & 15 & 0 & 11 & 1 & \begin{tabular}{|l|}
0 \\
\end{tabular} & 0 & 0 & 0 & 0 & 0 & 0 & 0 & 40 & 67 \\
\hline 69 & & $54 / 71 \mathrm{C}$ & 8 & 0 & 1 & 0 & \begin{tabular}{l|l|} 
\\
\end{tabular} & \begin{tabular}{|l|}
0 \\
\end{tabular} & 0 & 0 & 0 & 0 & 0 & 0 & 8 & 17 \\
\hline 72 & & 54/71AD & 9 & 0 & 0 & 0 & \begin{tabular}{l|l}
0 \\
\end{tabular} & 0 & 0 & 0 & 0 & 0 & 0 & 0 & 5 & 14 \\
\hline
\end{tabular}




\begin{tabular}{|c|c|c|c|c|c|c|c|c|c|c|c|c|c|c|c|c|}
\hline $\begin{array}{l}\frac{\pi}{0} \\
\frac{0}{0}\end{array}$ & 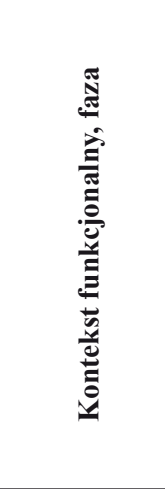 & $\frac{\hat{\theta}}{3}$ & 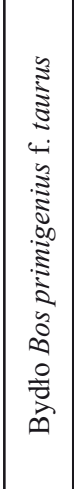 & 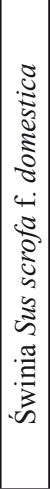 & 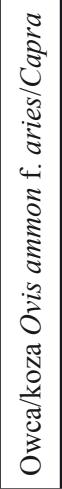 & 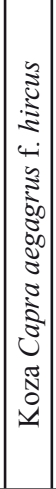 & 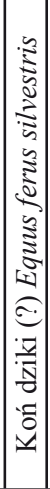 & 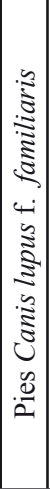 & 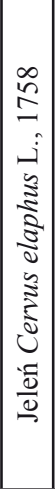 & 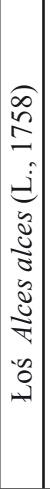 & 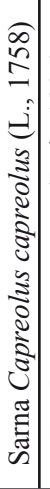 & 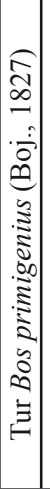 & 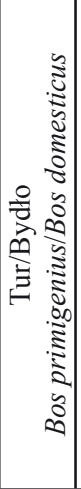 & 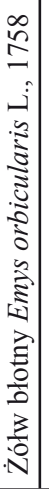 & 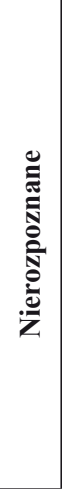 & 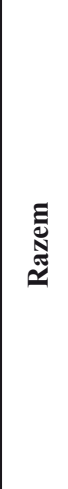 \\
\hline 74 & \multirow{9}{*}{ skupisko S } & $54 / 71 \mathrm{~A}$ & 122 & 6 & 5 & 0 & 0 & 0 & 6 & 0 & 1 & \begin{tabular}{l|l}
0 \\
\end{tabular} & 3 & 2 & 212 & 357 \\
\hline 79 & & $54 / 71 \mathrm{~A}$ & 24 & 5 & 6 & 0 & 0 & 0 & 2 & 0 & \begin{tabular}{l|l}
0 \\
\end{tabular} & 0 & 2 & 0 & 40 & 79 \\
\hline 81 & & $53 / 71 \mathrm{ABCD}$ & 0 & 0 & 0 & 0 & 0 & 0 & 0 & 0 & 0 & \begin{tabular}{|l|l}
0 \\
\end{tabular} & 0 & 0 & 1 & 1 \\
\hline 82 & & 53/70B & 0 & 0 & 0 & 0 & 0 & 0 & 0 & 0 & 0 & 0 & 0 & 0 & 2 & 2 \\
\hline 83 & & $53 / 71 \mathrm{~A}$ & 0 & 0 & 0 & 0 & 0 & 0 & 0 & 0 & 0 & \begin{tabular}{|l|l|}
0 \\
\end{tabular} & 0 & 0 & 3 & 3 \\
\hline 88 & & $52 / 69 \mathrm{~B}$ & 0 & 0 & 0 & 0 & 0 & 0 & 0 & 0 & 0 & 0 & 0 & 0 & 6 & 6 \\
\hline 89 & & $52 / 69 \mathrm{~B}$ & 0 & 0 & 1 & 0 & 0 & 0 & 0 & 0 & 0 & 0 & 0 & 0 & 2 & 3 \\
\hline 90 & & $52 / 69 \mathrm{BC}$ & 1 & 0 & 0 & 0 & 0 & 0 & 0 & 0 & 0 & 0 & 0 & 0 & 0 & 1 \\
\hline 91 & & $52 / 69 \mathrm{C}$ & 0 & 0 & 0 & 0 & 0 & 0 & 0 & 0 & 0 & 0 & 0 & 0 & 2 & 2 \\
\hline \multicolumn{3}{|c|}{ Razem skupisko S, faza II } & 516 & 19 & 84 & 5 & 1 & 4 & 44 & 4 & 1 & 8 & 17 & 2 & 979 & 1684 \\
\hline 104 & \multirow{6}{*}{ faza III } & $61 / 71 \mathrm{AB}$ & 1 & 0 & 0 & 0 & 0 & 0 & 0 & 0 & 0 & 0 & 0 & 0 & 0 & 1 \\
\hline 131 & & $61 / 71 \mathrm{D}$ & 4 & 0 & 0 & 0 & 0 & 0 & 0 & 0 & 0 & 0 & 0 & 0 & 3 & 7 \\
\hline 139 & & 61/72ABCD & 8 & 0 & 0 & 0 & 0 & 0 & 0 & 0 & 0 & 0 & 0 & 0 & 0 & 8 \\
\hline 140 & & $61 / 72 \mathrm{BC}$ & 7 & 0 & 0 & 0 & 0 & 0 & 0 & 0 & 0 & 0 & 0 & 0 & 0 & 7 \\
\hline 145 & & $61 / / 71 \mathrm{D}$ & 3 & 0 & 1 & 0 & 0 & 0 & 0 & 0 & 0 & 0 & 0 & 0 & 40 & 44 \\
\hline 145 & & $61 / 71 \mathrm{D}$ & 0 & 0 & 0 & 0 & 0 & 0 & 0 & 0 & 0 & 0 & 0 & 0 & 3 & 3 \\
\hline \multicolumn{3}{|c|}{ Razem faza III } & 1055 & 38 & 169 & 10 & 2 & 8 & 88 & 8 & 2 & 16 & 34 & 42 & 2004 & 3438 \\
\hline \multirow{12}{*}{\multicolumn{2}{|c|}{ warstwa }} & $50 / 71 \mathrm{D}$ & 0 & 0 & 0 & 0 & 0 & 0 & 0 & 0 & 0 & 0 & 0 & 0 & 2 & 2 \\
\hline & & $54 / 69$ & 9 & 0 & 1 & 0 & 0 & 0 & 0 & 0 & 0 & 0 & 0 & 0 & 6 & 16 \\
\hline & & $54 / 70 \mathrm{~A}$ & 2 & 0 & 0 & 0 & 0 & 0 & 0 & 0 & 0 & 0 & 0 & 0 & 4 & 6 \\
\hline & & $54 / 70 \mathrm{~B}$ & 23 & 1 & 6 & 0 & 0 & 0 & 0 & 0 & 0 & \begin{tabular}{|l|l|}
0 \\
\end{tabular} & 0 & 0 & 40 & 70 \\
\hline & & $54 / 70 \mathrm{D}$ & 7 & 0 & 2 & 0 & 0 & 0 & 0 & 0 & \begin{tabular}{l|l}
0 \\
\end{tabular} & 0 & 0 & 0 & 9 & 18 \\
\hline & & $54 / 71 \mathrm{~A}$ & 4 & 0 & 0 & 0 & 0 & 0 & 0 & 0 & 0 & 0 & 0 & 0 & 15 & 19 \\
\hline & & $55 / 70 \mathrm{~B}$ & 3 & 0 & 0 & 0 & 0 & 0 & 0 & 0 & 0 & \begin{tabular}{l|l}
0 \\
\end{tabular} & 0 & 0 & 15 & 18 \\
\hline & & $55 / 70 \mathrm{C}$ & 4 & 0 & 0 & 0 & 0 & 0 & 0 & 0 & 0 & 0 & 0 & 0 & 9 & 13 \\
\hline & & 55/71A & 7 & 0 & 0 & 0 & 0 & 0 & 0 & 0 & 0 & 0 & 0 & 0 & 0 & 7 \\
\hline & & $55 / 71 \mathrm{D}$ & 7 & 0 & 0 & 0 & 0 & 0 & 0 & 0 & \begin{tabular}{l|l}
0 \\
\end{tabular} & \begin{tabular}{|l|l|}
0 \\
\end{tabular} & 0 & 0 & 10 & 17 \\
\hline & & 56/71A & 2 & 0 & 0 & 0 & 0 & 0 & 0 & 0 & 0 & \begin{tabular}{|l|l|}
0 \\
\end{tabular} & 0 & 0 & 1 & 3 \\
\hline & & $56 / 72 \mathrm{AB}$ & 2 & 0 & 0 & 0 & 0 & 0 & 0 & 0 & 0 & \begin{tabular}{|l|l|}
0 \\
\end{tabular} & 0 & 0 & 3 & 5 \\
\hline \multicolumn{3}{|c|}{ Razem warstwa } & 2180 & 77 & 347 & 20 & 4 & 16 & 176 & 16 & 4 & 32 & 68 & 82 & 4122 & 7070 \\
\hline \multicolumn{3}{|c|}{ Razem } & 366 & 14 & 49 & 2 & 1 & 1 & 17 & 1 & 1 & \begin{tabular}{|l|l}
2 \\
\end{tabular} & 8 & 2 & & \\
\hline \multicolumn{3}{|c|}{ Rozpoznane $=464=100 \%$} & 78,9 & 3,0 & 10,6 & 0,4 & 0,2 & 0,2 & 3,7 & & & 0,4 & 1,7 & 0,4 & & 11111 \\
\hline
\end{tabular}


[192]

Aneks 2. Bocień, gm. Chełmża, stanowisko 5. Zestawienie szczątków kostnych według taksonów chronologiczno-kulturowych

\begin{tabular}{|c|c|c|c|c|c|c|c|c|c|c|c|c|c|c|c|c|}
\hline Okres/kultura & $\stackrel{0}{\stackrel{0}{*}}$ & 畄 & 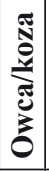 & 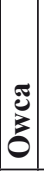 & & $\underline{\Delta}$ & 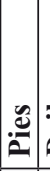 & 3 & 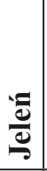 & $\mid$ & & $\exists$ & 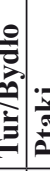 & 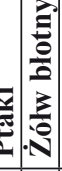 & 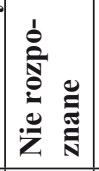 & $\underset{\Xi}{\Xi}$ \\
\hline KCWR & 366 & 14 & 49 & 0 & 2 & 1 & \begin{tabular}{|l|l}
1 & \\
\end{tabular} & \begin{tabular}{l|l}
0 & 1 \\
\end{tabular} & 17 & 1 & 1 & \begin{tabular}{l|l}
4 & $\varepsilon$ \\
\end{tabular} & \begin{tabular}{l|l}
8 & 0 \\
\end{tabular} & \begin{tabular}{|l|l|}
0 & 2 \\
\end{tabular} & 651 & 1115 \\
\hline KCWR/WBR,WS & 0 & 0 & 0 & 0 & 0 & 0 & \begin{tabular}{|l|l}
0 & \\
\end{tabular} & \begin{tabular}{l|l}
0 & $(10$ \\
\end{tabular} & 0 & 0 & 0 & \begin{tabular}{l|l}
0 & ( \\
\end{tabular} & \begin{tabular}{l|l}
0 & 0 \\
\end{tabular} & \begin{tabular}{|l|l|}
0 & 0 \\
\end{tabular} & 1 & 1 \\
\hline KAK, HALA & 0 & 0 & 0 & 0 & 0 & 0 & \begin{tabular}{|l|l}
0 & \\
\end{tabular} & \begin{tabular}{l|l}
0 & $(12$
\end{tabular} & 0 & 0 & 0 & \begin{tabular}{l|l}
0 & ( \\
\end{tabular} & \begin{tabular}{l|l}
0 & 0 \\
\end{tabular} & \begin{tabular}{|l|l|}
0 & 0 \\
\end{tabular} & 1 & 1 \\
\hline KAK, HALA/KPL,WS,NZ & 1 & 0 & 1 & & 0 & 0 & \begin{tabular}{|l|l}
0 & \\
\end{tabular} & \begin{tabular}{l|l}
0 & $(10$ \\
\end{tabular} & 0 & 0 & 0 & \begin{tabular}{l|l}
0 & ( \\
\end{tabular} & \begin{tabular}{l|l}
0 & 0 \\
\end{tabular} & \begin{tabular}{|l|l|}
0 & 0 \\
\end{tabular} & 0 & 2 \\
\hline KAK, PLOR & 0 & 0 & 0 & 0 & 0 & 0 & 0 & \begin{tabular}{l|l}
0 & $(1$ \\
\end{tabular} & 0 & 0 & 0 & \begin{tabular}{l|l}
0 & ( \\
\end{tabular} & \begin{tabular}{l|l}
0 & 0 \\
\end{tabular} & \begin{tabular}{|l|l|}
0 & 0 \\
\end{tabular} & 1 & 1 \\
\hline KAK,WBR/KCWR, SCHN & 0 & 0 & 0 & 0 & 0 & 0 & \begin{tabular}{|l|l}
0 & \\
\end{tabular} & \begin{tabular}{l|l}
0 & $(10$ \\
\end{tabular} & 0 & 0 & & \begin{tabular}{l|l}
0 & ( \\
\end{tabular} & \begin{tabular}{l|l}
0 & 0 \\
\end{tabular} & \begin{tabular}{|l|l|}
0 & 0 \\
\end{tabular} & 3 & 3 \\
\hline HALA & 0 & 0 & 0 & 0 & 0 & 0 & 0 & \begin{tabular}{l|l}
0 & $(12$ \\
\end{tabular} & 0 & 0 & 0 & \begin{tabular}{l|l}
0 & ( \\
\end{tabular} & \begin{tabular}{l|l}
0 & 0 \\
\end{tabular} & \begin{tabular}{|l|l|}
0 & 0 \\
\end{tabular} & 7 & 7 \\
\hline HALA, PLOR & 0 & 0 & 0 & 0 & 0 & 0 & \begin{tabular}{|l|l}
0 \\
\end{tabular} & \begin{tabular}{l|l}
0 & $(1$ \\
\end{tabular} & 0 & \begin{tabular}{|l|l|}
0 \\
\end{tabular} & 0 & \begin{tabular}{l|l}
0 & $(1$ \\
\end{tabular} & \begin{tabular}{l|l}
0 & 0 \\
\end{tabular} & \begin{tabular}{|l|l|}
0 & 0 \\
\end{tabular} & 1 & 1 \\
\hline HALA, PLOR, NZ & 0 & 0 & 0 & 0 & 0 & 0 & \begin{tabular}{|l|l}
0 & \\
\end{tabular} & \begin{tabular}{l|l}
0 & $(10$ \\
\end{tabular} & 0 & \begin{tabular}{|l|l}
0 \\
\end{tabular} & 0 & \begin{tabular}{l|l}
0 & ( \\
\end{tabular} & \begin{tabular}{l|l}
0 & 0 \\
\end{tabular} & \begin{tabular}{|l|l|}
0 & 0 \\
\end{tabular} & 1 & 1 \\
\hline $\begin{array}{l}\text { HALA, PLOR, WS/KAK, } \\
\text { SCH }\end{array}$ & 1 & 0 & 0 & 0 & 0 & 0 & 0 & 0 & 0 & 0 & 0 & 0 ( & $0 \mid 0$ & 00 & 0 & 1 \\
\hline HALA/KAK & 0 & 0 & 0 & 0 & 0 & 0 & \begin{tabular}{|l|l}
0 & 1 \\
\end{tabular} & \begin{tabular}{l|l}
0 & $(10$
\end{tabular} & 0 & 0 & 0 & \begin{tabular}{l|l}
0 & ( \\
\end{tabular} & \begin{tabular}{l|l}
0 & 0 \\
\end{tabular} & \begin{tabular}{|l|l|}
0 & 0 \\
\end{tabular} & 1 & 1 \\
\hline HALA/KAK, PLOR & 0 & 0 & 0 & 0 & 0 & 0 & \begin{tabular}{|l|l}
0 & \\
\end{tabular} & \begin{tabular}{l|l}
0 & $(10$ \\
\end{tabular} & 0 & 0 & 0 & \begin{tabular}{l|l}
0 & ( \\
\end{tabular} & \begin{tabular}{l|l}
0 & 0 \\
\end{tabular} & \begin{tabular}{|l|l|}
0 & 0 \\
\end{tabular} & 2 & 2 \\
\hline HALA/KAK, PLOR,WS & 2 & 0 & 0 & 0 & 0 & 0 & \begin{tabular}{|l|l}
0 & \\
\end{tabular} & 0 & 0 & 0 & 0 & \begin{tabular}{l|l}
0 & ( \\
\end{tabular} & \begin{tabular}{l|l}
0 & 0 \\
\end{tabular} & \begin{tabular}{|l|l|}
0 & 0 \\
\end{tabular} & 0 & 2 \\
\hline HALA/KCWR & 0 & 0 & 0 & 0 & 0 & 0 & 0 & \begin{tabular}{l|l}
0 & $(10$ \\
\end{tabular} & 0 & 0 & 0 & \begin{tabular}{l|l}
0 & ( \\
\end{tabular} & \begin{tabular}{l|l}
0 & 0 \\
\end{tabular} & \begin{tabular}{|l|l|}
0 & 0 \\
\end{tabular} & 3 & 3 \\
\hline HALA/KCWR, KAK & 0 & 0 & 0 & 0 & 0 & 0 & \begin{tabular}{|l|l}
0 & \\
\end{tabular} & \begin{tabular}{l|l}
0 & $(1$ \\
\end{tabular} & 0 & 0 & 0 & \begin{tabular}{l|l}
0 & ( \\
\end{tabular} & \begin{tabular}{l|l}
0 & 0 \\
\end{tabular} & \begin{tabular}{|l|l|}
0 & 0 \\
\end{tabular} & 3 & 3 \\
\hline HALA/KCWR, PLOR & 0 & 0 & 0 & 0 & 0 & 0 & \begin{tabular}{|l|l}
0 & \\
\end{tabular} & \begin{tabular}{l|l}
0 & $(12$
\end{tabular} & 0 & 0 & 0 & \begin{tabular}{l|l}
0 & $(1$ \\
\end{tabular} & \begin{tabular}{l|l}
0 & 0 \\
\end{tabular} & \begin{tabular}{|l|l|}
0 & 0 \\
\end{tabular} & 2 & 2 \\
\hline HALA/KPCW & 0 & 0 & 0 & 0 & 0 & 0 & 0 & \begin{tabular}{l|l}
0 & $(12$ \\
\end{tabular} & 0 & 0 & 0 & \begin{tabular}{l|l}
0 & ( \\
\end{tabular} & \begin{tabular}{l|l}
0 & 0 \\
\end{tabular} & \begin{tabular}{|l|l|}
0 & 0 \\
\end{tabular} & 2 & 2 \\
\hline \begin{tabular}{|l} 
HALA/PLOR \\
\end{tabular} & 0 & 0 & 0 & 0 & 0 & 0 & \begin{tabular}{|l|l}
0 \\
\end{tabular} & \begin{tabular}{l|l}
0 & 1 \\
\end{tabular} & 0 & \begin{tabular}{|l|l|}
0 \\
\end{tabular} & 0 & \begin{tabular}{l|l}
0 & $(1$ \\
\end{tabular} & \begin{tabular}{l|l}
0 & 0 \\
\end{tabular} & \begin{tabular}{|l|l|}
0 & 0 \\
\end{tabular} & 6 & 6 \\
\hline HALA/PLOR,WS & 0 & 0 & 0 & \begin{tabular}{|l|l|}
0 \\
\end{tabular} & 0 & 0 & \begin{tabular}{|l|l}
0 & \\
\end{tabular} & \begin{tabular}{l|l}
0 & \\
\end{tabular} & 0 & 0 & 0 & \begin{tabular}{l|l}
0 & ( \\
\end{tabular} & \begin{tabular}{l|l}
0 & 0 \\
\end{tabular} & \begin{tabular}{|l|l|}
0 & 0 \\
\end{tabular} & 1 & 1 \\
\hline HALA/SCHN,PLOR & 1 & 0 & 0 & 0 & 0 & 0 & 0 & \begin{tabular}{l|l}
0 & $(1$ \\
\end{tabular} & 0 & 0 & 0 & \begin{tabular}{l|l}
0 & ( \\
\end{tabular} & \begin{tabular}{l|l}
0 & 0 \\
\end{tabular} & \begin{tabular}{|l|l|}
0 & 0 \\
\end{tabular} & 1 & 2 \\
\hline HALA/WS & 0 & 0 & 0 & 0 & 0 & 0 & \begin{tabular}{|l|l}
0 & \\
\end{tabular} & \begin{tabular}{l|l}
0 & $(10$ \\
\end{tabular} & 0 & \begin{tabular}{|l|l}
0 \\
\end{tabular} & 0 & \begin{tabular}{l|l}
0 & ( \\
\end{tabular} & \begin{tabular}{l|l}
0 & 0 \\
\end{tabular} & \begin{tabular}{|l|l|}
0 & 0 \\
\end{tabular} & 1 & 1 \\
\hline WEŻ/WS & 2 & 0 & 0 & 0 & 0 & 0 & \begin{tabular}{|l|l}
0 & \\
\end{tabular} & 18 & 0 & \begin{tabular}{|l|l}
0 \\
\end{tabular} & 0 & \begin{tabular}{l|l}
0 & ( \\
\end{tabular} & \begin{tabular}{l|l}
0 & 0 \\
\end{tabular} & \begin{tabular}{|l|l|}
0 & 0 \\
\end{tabular} & 2 & 5 \\
\hline PLOR & 2 & 0 & 1 & 0 & 0 & 1 & 0 & \begin{tabular}{l|l}
0 & $(12$ \\
\end{tabular} & 0 & 0 & 0 & \begin{tabular}{l|l}
0 & $(1$ \\
\end{tabular} & \begin{tabular}{l|l}
0 & 0 \\
\end{tabular} & \begin{tabular}{|l|l|}
0 & 0 \\
\end{tabular} & 7 & 11 \\
\hline PLOR,WS & 0 & 0 & 0 & 0 & 0 & 0 & \begin{tabular}{|l|l}
0 \\
\end{tabular} & \begin{tabular}{l|l}
0 & 1 \\
\end{tabular} & 0 & 0 & 0 & \begin{tabular}{l|l}
0 & ( \\
\end{tabular} & \begin{tabular}{l|l}
0 & 0 \\
\end{tabular} & \begin{tabular}{|l|l|}
0 & 0 \\
\end{tabular} & 1 & 1 \\
\hline PLOR/HALA & 1 & 0 & 0 & \begin{tabular}{|l|l|}
0 \\
\end{tabular} & 0 & 0 & \begin{tabular}{|l|l}
0 & \\
\end{tabular} & \begin{tabular}{l|l}
0 & $(10$
\end{tabular} & 0 & \begin{tabular}{|l|l|}
0 & \\
\end{tabular} & 0 & \begin{tabular}{l|l}
0 & ( \\
\end{tabular} & \begin{tabular}{l|l}
0 & 0 \\
\end{tabular} & \begin{tabular}{|l|l|}
0 & 0 \\
\end{tabular} & 3 & 4 \\
\hline PLOR/HALA,WS & 0 & 0 & 0 & 0 & 0 & 0 & 0 & \begin{tabular}{l|l}
0 & $(10$ \\
\end{tabular} & 0 & 0 & 0 & \begin{tabular}{l|l}
0 & ( \\
\end{tabular} & \begin{tabular}{l|l}
0 & 0 \\
\end{tabular} & \begin{tabular}{|l|l|}
0 & 0 \\
\end{tabular} & 5 & 5 \\
\hline PLOR/WS & 0 & 0 & 0 & 0 & 0 & 0 & \begin{tabular}{|l|l}
0 & \\
\end{tabular} & \begin{tabular}{l|l}
0 & $(1$ \\
\end{tabular} & 0 & \begin{tabular}{|l|l}
0 \\
\end{tabular} & 0 & \begin{tabular}{l|l}
0 & ( \\
\end{tabular} & \begin{tabular}{l|l}
0 & 0 \\
\end{tabular} & \begin{tabular}{|l|l|}
0 & 0 \\
\end{tabular} & 5 & 5 \\
\hline MOPR & 0 & 2 & 1 & 11 & 0 & 0 & \begin{tabular}{|l|l}
0 & \\
\end{tabular} & \begin{tabular}{l|l}
0 & $(10$ \\
\end{tabular} & 0 & \begin{tabular}{|l|l|}
0 \\
\end{tabular} & 0 & \begin{tabular}{l|l}
0 & ( \\
\end{tabular} & \begin{tabular}{l|l}
0 & 0 \\
\end{tabular} & \begin{tabular}{|l|l|}
0 & 0 \\
\end{tabular} & 0 & 4 \\
\hline WS & 7 & 0 & 0 & 0 & 1 & 0 & \begin{tabular}{|l|l|l}
0 & \\
\end{tabular} & \begin{tabular}{l|l}
0 & \\
\end{tabular} & 0 & 0 & 0 & \begin{tabular}{l|l}
0 & ( \\
\end{tabular} & \begin{tabular}{l|l}
0 & 0 \\
\end{tabular} & \begin{tabular}{|l|l|}
0 & 0 \\
\end{tabular} & 18 & 26 \\
\hline $\begin{array}{l}\text { WS, HALA/KCWR, KAK, } \\
\text { NZ }\end{array}$ & 2 & 0 & 0 & 0 & 0 & 0 & 0 & 0 & 0 & 0 & 0 & 0 & \begin{tabular}{l|l}
0 & 0
\end{tabular} & 00 & 0 & 2 \\
\hline $\mathrm{NZ}$ & 0 & 0 & 0 & \begin{tabular}{|l|l|}
0 \\
\end{tabular} & \begin{tabular}{l|l}
0 \\
\end{tabular} & 0 & \begin{tabular}{|l|l|}
0 & \\
\end{tabular} & 0 & 0 & \begin{tabular}{|l|l|}
0 & \\
\end{tabular} & 0 & \begin{tabular}{l|l}
0 & $(1$ \\
\end{tabular} & \begin{tabular}{l|l}
0 & 0 \\
\end{tabular} & \begin{tabular}{|l|l|}
0 & 0 \\
\end{tabular} & 2 & 2 \\
\hline $\mathrm{N}$ & 14 & 1 & 7 & 0 & \begin{tabular}{l|l} 
\\
\end{tabular} & 1 & \begin{tabular}{|l|l}
0 & \\
\end{tabular} & \begin{tabular}{l|l}
0 & \\
\end{tabular} & 0 & \begin{tabular}{|l|l|}
0 & \\
\end{tabular} & 0 & \begin{tabular}{l|l}
0 & ( \\
\end{tabular} & \begin{tabular}{l|l}
0 & 2 \\
\end{tabular} & \begin{tabular}{|l|l|}
2 & 0 \\
\end{tabular} & 39 & 64 \\
\hline
\end{tabular}

